\title{
Isolation, characterization and in vitro cytotoxicity of new sesquiterpenoids from Achillea clavennae
}

\begin{tabular}{|c|c|}
\hline Journal: & Planta Medica \\
\hline Manuscript ID: & PLAMED-2013-05-0502-OP.R2 \\
\hline Manuscript Type: & Original Papers \\
\hline Date Submitted by the Author: & $\mathrm{n} / \mathrm{a}$ \\
\hline \multirow[t]{2}{*}{ Complete List of Authors: } & $\begin{array}{l}\text { Trifunović, Snežana; Faculty of Chemistry, University of Belgrade, } \\
\text { Isakovic, Andjelka; School of Medicine, University of Belgrade, Institute of } \\
\text { Biochemistry } \\
\text { Isakovic, Aleksandra; School of Medicine, University of Belgrade, Institute } \\
\text { of medical and clinical biochemistry } \\
\text { Vučković, Ivan; Faculty of Chemistry, University of Belgrade, } \\
\text { Mandić, Boris; Faculty of Chemistry, University of Belgrade, } \\
\text { Novakovic, Miroslav; Institute of Chemistry, Technology and Metallurgy, } \\
\text { University of Belgrade, } \\
\text { Vajs, Vlatka; Institute of Chemistry, Technology and Metallurgy, University } \\
\text { of Belgrade, } \\
\text { Milosavljević, Slobodan; Faculty of Chemistry, University of Belgrade, } \\
\text { Trajkovic, Vladimir; School of Medicine, University of Belgrade, Institute of } \\
\text { microbiology and immunology }\end{array}$ \\
\hline & $\begin{array}{l}\text { Chemosystematics < Botany, Preparative Chromatography < Extraction, } \\
\text { Isolation, Apoptosis < Molecular Targets and Activities, Cytotoxic, Cancer- } \\
\text { related < Molecular Targets and Activities, GC-MS < Natural Products } \\
\text { Analysis, MS < Natural Products Analysis, NMR < Natural Products } \\
\text { Analysis, Sequiterpenes < Isoprenoids < Natural Products Classes }\end{array}$ \\
\hline
\end{tabular}

\section{SCHOLARONE \\ Manuscripts}


Dear Prof. Merfort,

Please find attached the revised manuscript PLAMED-2013-05-0502-OP.R1 entitled "Isolation, characterization and in vitro cytotoxicity of new sesquiterpenoids from Achillea clavennae" by Snežana Trifunović, Anđelka M. Isaković, Aleksandra Isaković, Ivan Vučković, Boris Mandić, Miroslav Novaković, Vlatka Vajs, Slobodan Milosavljević and Vladimir Trajković.

We have accepted all suggestions and made appropriate corrections designated in yellow color in the revised manuscript. We hope that our answers will satisfy your criteria and criteria of reviewer(s). The manuscript has been corrected by a native English speaker.

\author{
Sincerely yours, \\ Dr. Snežana Trifunović \\ Faculty of Chemistry, University of Belgrade \\ snezanat@chem.bg.ac.rs
}




\title{
Responses to Reviewers
}

\author{
Abstract: \\ - Please use Achillea clavennae in the abstract and not only the abbreviation A. clavennae. Please \\ add also partly in this way "...inducing partly apoptotic death..." (see comment above. \\ Both corrections have been made. \\ Introduction: \\ - Correct page 8, lane 9: flavonoids aglycons \\ The correction has been made. \\ - Please delete structures of compounds 7-10 from Fig 1, as they have already been isolated \\ from the same plant. Compound 4 can remain as this compound was included in the cytotoxicity \\ assay.
}

The structures of compounds 7 - 10 from Fig. 1 have been deleted. Consequently, oleanolic acid has been assigned a number 7 (before 11). Also, sentences which refer to Fig. 1 (or deleted compounds) have been rewritten:

Abstract: page 2, lines 5 - 7 (revised manuscript)

Introduction: page 4, lines 10 and 11

Results and discussion: page 4, lines $20-23$, and page 5, line 1

Materials and methods (Extraction and isolation): page 14, lines 15, 17, 23, 24, and page 15, lines 1 and 2

Figure legends: Fig. 1 "The structures of compounds 1-11." have been replaced with "The structures of compounds $1-7$. "

Results and discussion:

- Nomenclature should always be the same: 
Page 10, lane 7: correct: ... and C-10(14) double bonds

Correct: page 11, lane 7: .....4,10(14)-

Correct: page 11, lane 22: ...10(14)

It is not necessay to write $4(5)$, it is sufficient 4

The authors have correctly considered this by the chemical name.

We agree with the referee. All corrections have been made.

Page 5, line 12 (revised manuscript): C-4(5) and C-10 has been replaced with C-4 and C10(14)

Page 6, line 12: $\Delta^{4(5), 10}$-germacranolides has been replaced with $\Delta^{4,10(14)}$-germacranolides Page 7, line 4: $\Delta^{4(5)}$ and $\Delta^{10}$ has been replaced with $\Delta^{4}$ and $\Delta^{10(14)}$

- Page 13, lane 2: please simplify: ....indicated C-5 to be quarternary

The correction has been made (page 8, line 7)

- Please give the exact IC50 values of compounds 3, 4 and cisplatin in U251 and C6 cells including standard deviation. Moreover, the authors write in the figure legend that "the results are presented as mean + SD values of triplicates from a representative of three independent experiments". The authors must give the results from the three independent experiments!! And not only from one experiment with three technical replicates.

In accordance with the referee's request, we have presented the mean $\mathrm{IC}_{50}$ values (with SD) for each compound (Table 2) and briefly discussed their efficiency in the revised manuscript (page 10, lines 12 - 17). Also, we have presented results in Fig. 4 as mean \pm SD values from three independent experiments, as stated in the revised manuscript (Fig. 4 legend).

- Looking at Fig. 5A no concentration dependent activation in U251 cells can be observed, but slightly in C6 cells. Please correct this in the manuscript.

To comply with the referee's suggestion, we have deleted the words "dose-dependent". Figure legend 5: please indicate more clearly where a concentration of 25 micromolar and where 12.5 and 25 micromolar concentrations were used. 
We have corrected the Fig. 5 legend to indicate more clearly where a concentration of 25 $\mu M$ and where 12.5 and $25 \mu M$ concentrations were used.

There is a discrepancy between Fig 5C and the manuscript: $32.8 \%$ annexin+ cells???

The percentage of $\mathrm{U} 251$ annexin ${ }^{+}$cells in Fig. $5 \mathrm{C}$ is $22.7 \%$ annexin ${ }^{+} \mathrm{PI}^{-}+10.1 \%$ annexin ${ }^{+} \mathrm{PI}^{+}$ $\mathbf{3 2 . 8 \%}$.

- The authors have shown that their sesquiterpene lactones induce ROS production, however they did not prove the correlation to apoptosis! This can only been done if they have added an antioxidans together with their compounds and studied cell death. From their results it is also clear that cells not only die from apoptosis. This has to be mentioned.

The referee is correct in observing that our data do not directly confirm the involvement of oxidative stress in the observed cytotoxicity, so the statements to this effect have been included in the revised manuscript (page 12, lines $6-8$ and page 12, lines $23-24$ ). Also, the possibility that compound 3 actually induced mixed apoptotic/necrotic death has been briefly discussed (page 11, lines 16 - 19).

- It would be favourable that the manuscript is corrected by a native English speaker.

The manuscript has been corrected by a native English speaker. 
1 Isolation, characterization and in vitro cytotoxicity of new sesquiterpenoids

4 Snežana Trifunović ${ }^{1}$, Anđelka M. Isaković ${ }^{2}$, Aleksandra Isaković2 ${ }^{2}$ Ivan Vučković ${ }^{1}$, Boris

5 Mandić $^{1}$, Miroslav Novaković ${ }^{3}$, Vlatka Vajs ${ }^{3}$, Slobodan Milosavljević ${ }^{1}$ and Vladimir Trajković $^{4}$

6

$7 \quad{ }^{1}$ Faculty of Chemistry, University of Belgrade, Studentski trg 12-16, 11000 Belgrade, Serbia

$8{ }^{2}$ Institute of Medical and Clinical Biochemistry, School of Medicine, University of Belgrade,

9 Pasterova 2, 11000 Belgrade, Serbia

$10{ }^{3}$ Institute of Chemistry, Technology and Metallurgy, University of Belgrade, Studentski trg 12-

$11 \quad 16,11000$ Belgrade, Serbia

$12{ }^{4}$ Institute of Microbiology and Immunology, School of Medicine, University of Belgrade, Dr

13 Subotica 1, 11000 Belgrade, Serbia

16 Correspondence:

17 Dr. Snežana Trifunović, Faculty of Chemistry, University of Belgrade, Studentski trg 12-16, 1811000 Belgrade, Serbia; E-mail: snezanat@chem.bg.ac.rs; Phone: +381 11 2630474; Fax: +381

$19 \quad 112636061$

20 Prof. Vladimir Trajković, Institute of Microbiology and Immunology, School of Medicine, 21 University of Belgrade, $\operatorname{Dr}$ Subotića 1, 11000 Belgrade, Serbia; E-mail: 22 vtrajkovic@med.bg.ac.rs; Phone: +381 11 3643233; Fax: +381 113643235 


\section{Abstract}

2

3 Further phytochemical investigation into the aerial parts of Achillea clavennae has resulted in the

4 isolation of three new sesquiterpene lactones: two highly oxygenated germacranolides $(\mathbf{1}, \mathbf{2})$ and

5 the iso-seco-guaianolide, 9(R)-acetoxy-3-O-methyl-iso-seco-tanapartholide (3). Eight known

6 compounds were also found in this plant species, of which $9 \alpha$-acetoxycanin (5), $\operatorname{sintenin}(\mathbf{6})$ and

7 oleanolic acid (7) were detected for the first time. The structures of the isolated compounds were

8 elucidated by combined spectroscopic methods (1D and 2D NMR, HRESIMS, CIMS, FTIR).

9 While the predominant metabolite germacranolide sintenin (6) was not cytotoxic, the new iso-

10 seco-guaianolide (3) displayed cytotoxicity comparable to that of cisplatin and the lactone

11 apressin (4), inducing partly apoptotic death in human U251 and rat C6 glioma cell lines.

15 Key words: Achillea clavennae L. (Asteraceae), sesquiterpene lactones, iso-seco-guaianolide, 16 NMR, cytotoxicity, apoptosis 


\section{Introduction}

2

3 The genus Achillea L. contains over 100 species, mainly distributed in Europe and the temperate 4 areas of Asia [1]. Hitherto, about sixty Achillea species have been phytochemically investigated, 5 but far fewer have been biologically tested [2-3]. The composition and antibacterial activities of

6 the essential oils have been examined the most, even many times for same species, as in the case

7 of $A$. millefolium, the most popular and wide-spread species of the genus. Alkamides from the

8 roots were studied in detail, as compounds initially considered relevant for chemotaxonomy.

9 Nowadays, the leaf exudates (mainly containing flavonoid aglycons) are most frequently

10 analyzed for this purpose. The main constituents of the investigated plant extracts are terpenoids

11 (largely sesquiterpene lactones) and flavonoids, classes of compounds with documented

12 biological activity [2-3]. This fact, as well as the use of many Achillea species in traditional

13 medicine worldwide (for their anti-inflammatory, antispasmodic, stomachic, digestive,

14 cholagogue, antipyretic, emmenagogue, hemostatic, hypotensive, diuretic and urinary antiseptic

15 activities), makes this genus interesting for extensive examination.

16 Achillea clavennae, which is the subject of the present study, grows on the elevated carbonate

17 rocks of the eastern and southern Alps, as well as on mountains in the western part of the Balkan

18 Peninsula (at altitudes between 1500 and $2500 \mathrm{~m}$ ). According to the morphological characters

19 and flavonoid profiles, A. clavennae belongs to the group of alpine species (the subgroup $A$.

20 moschata) of the section Ptarmica (Mill.) W.D.J. [4]. This species was discovered and described

21 as a healing plant (cholagogue, stomachic and anthelmintic) at the beginning of the $17^{\text {th }}$ century

22 [5]. At present, it is used in Croatian folk medicine to treat abdominal pain, the common cold,

23 influenza and respiratory disorders [6]. Examination of the essential oil of $A$. clavennae from this

24 locality verified its high antibacterial activity against some respiratory tract pathogens [6-7]. The 
1 extract of a plant collection from Macedonia (containing alkanes, fatty acids, monoterpenes,

2 guaiane sesquiterpenes and flavonoids) also exhibited a wide range of antimicrobial activities [8].

3 Our previous study of the aerial parts of A. clavennae from Montenegro (the Komovi Mountain)

4 revealed that guaianolides, bisabolenes and flavonoids were its main constituents. Subsequent

5 work, which was the first assessment of the biological activity of A. clavennae constituents,

6 revealed a remarkably high cytotoxic activity of the lactones $9 \alpha$-acetoxyartecanin and apressin 7 [9].

8 In the present study, the aerial parts of this alpine species from the Prokletije Mountains

9 (Montenegro) were analyzed. Three new sesquiterpene lactones (1-3) and eight known

10 compounds (apressin (4), $9 \alpha$-acetoxycanin (5), sintenin (6), oleanolic acid (7), chrysetunone, 11 -

11 dehydroxy,11-hydroperoxyindicumenone, sesamin, centaureidin) were isolated and structurally

12 determined. In addition, the in vitro cytotoxic activity of the predominant lactones $\mathbf{3}, \mathbf{4}$ and $\mathbf{6}$ was

13 examined.

15 Results and Discussion

17 Fractionation of the crude extract (petrol- $\mathrm{Et}_{2} \mathrm{O}-\mathrm{MeOH}, 1: 1: 1$ ) of the air-dried aerial parts of the 18 title plant, by repeated silica gel column chromatography and preparative TLC, gave six 19 sesquiterpene lactones (new lactones 1-3, apressin (4) [10], $9 \alpha$-acetoxycanin (5) [11] and sintenin 20 (6) [12]), two bisabolenes (chrysetunone [13] and 11-dehydroxy,11-hydroperoxyindicumenone 21 [9]), lignan sesamin [14], flavonol centaureidin [15], and oleanolic acid (7) [16] (Fig. 1). 22 Apressin (4), chrysetunone, 11-dehydroxy,11-hydroperoxyindicumenone, sesamin and 23 centaureidin had already been identified in the aerial parts of $A$. clavennae [9], but compounds $\mathbf{5}$, 
16 , and 7 were found for the first time in this plant species. Oleanolic acid, atypical for the genus 2 Achillea, had previously been reported only in A. teretifolia [17]. Bisabolene derivatives also 3 rarely occur in this genus (A. odorata [18], A. cretica [19] and A. clavennae [9]), especially 4 hydroperoxy-bisabolenes, previously found only in A. clavennae.

5

$6 \quad$ Fig. 1

8 The molecular formula $\mathrm{C}_{19} \mathrm{H}_{24} \mathrm{O}_{8}$, for the lactone $\mathbf{1}$, was deduced from the positive-ion mode 9 HRESIMS $\left(\mathrm{m} / \mathrm{z} 381.15398[\mathrm{M}+\mathrm{H}]^{+}\right.$; calc. 381.15439). The CI mass spectrum showed the 10 pseudomolecular ion, $\left[\mathrm{MH}-\mathrm{O}_{2}\right]^{+}\left(\mathrm{m} / \mathrm{z}\right.$ 349), $\left[\mathrm{MH}-\mathrm{O}_{2}-\mathrm{HOAc}\right]^{+}(\mathrm{m} / \mathrm{z} 289)$ and $[\mathrm{MH}-2 \mathrm{HOAc}]^{+}(\mathrm{m} / z$ 11 261) ions, indicating the presence of the hydroperoxy and two acetoxy groups. The 12 germacranolide core of $\mathbf{1}$, with C-4 and C-10(14) double bonds, $\alpha$-methylene- $\gamma$-lactone group and 13 the substitution at C-1, C-3 and C-9, was recognized in ${ }^{1} \mathrm{H}$ NMR spectrum (Table 1). Singlets at $14 \delta 2.03$ and $\delta 2.08$, and broad singlet at $\delta 8.75$ originated from two OAc and HOO groups, 15 respectively. Low-field signals at $\delta 5.33 d d\left(J_{1}=5.0 \mathrm{~Hz}, J_{2}=11.5 \mathrm{~Hz}\right), \delta 5.14 \mathrm{brd}(J=10.5 \mathrm{~Hz})$ 16 and $\delta 4.24 \mathrm{brd}(J=10.0 \mathrm{~Hz})$ belonged to their geminal protons: H-3, H-9 and H-1. H-3 was 17 distinguished on the basis of HMBC correlations $\mathrm{H}-3(\delta 5.33) / \mathrm{C}-5$ and $\mathrm{H}_{3}-15 / \mathrm{C}-3(\delta$ 75.6). 18 Carbons at $\delta 76.8$ and $\delta 86.1$, connected in the HSQC spectrum with protons at $\delta 5.14$ and $\delta 4.24$, 19 respectively, showed $\mathrm{HMBC}$ correlations with $\mathrm{H}_{2}-14$, which only proves $\mathrm{C}-9$ and $\mathrm{C}-1$ positions 20 of remaining substituents. Other significant HMBC correlations regarding the arrangement of this 21 part of molecule were missing. Taking into account the presence of the lactone sintenin in this 22 plant sample (biogenetically related to 1), and COSY and NOESY correlations (Fig. 2) of the 23 proton geminal to OAc $(\delta 5.14)$, as well as of $\mathrm{H}$ geminal to $\mathrm{OOH}(\delta 4.24)$, it was deduced that the 
1 former proton is $\mathrm{H}-9$ and the latter is H-1. Moreover, NOEs H-9/ H-7, H- $8 \alpha, \mathrm{H}-1$ and $\mathrm{H}-1 / \mathrm{H}-2 \alpha$,

2 H-3, H-5 revealed $\alpha$-position of these protons, hence $\beta$-position of all substituents. One more

3 high-frequency shifted $\operatorname{brd}(J=10.5 \mathrm{~Hz})$ at $\delta 5.45$ was assigned to $\mathrm{H}-5$ on the basis of HMBC

4 correlations $\mathrm{H}_{3}-15, \mathrm{H}-3 / \mathrm{C}-5(122.2)$. Due to the lack of the important HMBC correlations,

5 coupling patterns in COSY spectrum and NOESY cross-peaks (Fig. 2) were crucial for

6 distinguishing $\mathrm{CH}_{2}-2$ and $\mathrm{CH}_{2}-8$ groups, as well as identifying $\alpha$ and $\beta$ protons. NOEs $\mathrm{H}-6 / \mathrm{H}_{3}-15$

7 and $\mathrm{H}_{3}-15 / \mathrm{H}-14$ ' disclosed syn-orientation of $\mathrm{Me}-15$ and $\mathrm{CH}_{2}-14$ on the $\beta$-face of the trans-4-

8 cyclodecene. Such geometry affects spatial closeness of $\alpha$-pseudo-axial protons H-1, H-3, H-5

9 and $\mathrm{H}-9$, as well as of $\beta$-pseudo-axial $\mathrm{H}-2$ with $\mathrm{H}-14$ ' and Me- 15 , and also $\mathrm{H}-8 \beta$ with $\mathrm{H}-14$ and

10 H-6, which was evidenced by corresponding NOE correlations (Fig. 2). Finally, 1 was identified

11 as $3 \beta, 9 \beta$-diacetoxy-1 $\beta$-hydroperoxy- $6 \beta, 7 \alpha \mathrm{H}$-germacra-4,10(14),11(13)-trien-12,6 $\alpha$-olide. Three

12 substituted $\Delta^{4,10(14)}$-germacranolides have not previously been found in the genus Achillea.

14 Fig. 2

16 For lactone $\mathbf{2}$, closely related to $\mathbf{1}$, the structure was determined from the positive-ion mode 17 HRESIMS, CIMS, and ${ }^{1} \mathrm{H}$ NMR spectra. Prior to recording 2D NMR spectra, this compound was 18 decomposed in the NMR tube, therefore the stereochemical data were obscured. According to $19[\mathrm{M}+\mathrm{H}]^{+}$ion at $\mathrm{m} / \mathrm{z} 367.17513$ (calc. 367.17485 ) in HRESIMS the molecular formula $\mathrm{C}_{19} \mathrm{H}_{26} \mathrm{O}_{7}$ 20 was established. CI mass spectrum contained [MH-HOAc] ${ }^{+}(\mathrm{m} / \mathrm{z} 307),\left[\mathrm{MH}-\mathrm{HOAc}-\mathrm{H}_{2} \mathrm{O}\right]^{+}(\mathrm{m} / \mathrm{z}$ $21289)$ and $[\mathrm{MH}-2 \mathrm{HOAc}]^{+}(\mathrm{m} / \mathrm{z} 247)$ ions, implying the existence of a hydroxy group (instead of 22 hydroperoxy in comparison with 1) and two acetoxy groups in the molecule. The similarity of the $23{ }^{1} \mathrm{H}$ NMR data of $\mathbf{2}$ (Table 1) to that of $\mathbf{1}$ indicated the same basic structure. ${ }^{1} \mathrm{H}$ NMR spectrum of 
12 exhibited signals of two acetoxy groups ( $\delta 2.03 s$ and $\delta 2.08 s$, respectively) and their geminal

2 protons at $\delta 5.29 d d\left(J_{l}=5.0 \mathrm{~Hz}, J_{2}=11.4 \mathrm{~Hz}, \mathrm{H}-3\right)$ and $\delta 5.10 \mathrm{brdd}\left(J_{l}=3.2 \mathrm{~Hz}, \mathrm{~J}_{2}=7.6 \mathrm{~Hz}, \mathrm{H}-\right.$

3 9). Signals of $\mathrm{H}-5(\delta 5.39 \mathrm{brd}, J=10.4 \mathrm{~Hz}), \mathrm{Me}-15(\delta 1.58 d, J=1.6 \mathrm{~Hz}), \mathrm{H}-14(\delta 5.56 \mathrm{brs})$ and

$4 \quad \mathrm{H}-14^{\prime}(\delta 5.48 \mathrm{brs})$ documented double bonds $\Delta^{4}$ and $\Delta^{10(14)}$, respectively. Broad doublet at $\delta 4.16$

$5 \quad(J=9.8 \mathrm{~Hz})$ originated from $\mathrm{H}-1$, which is geminal to the hydroxy group. Missing the

6 characteristic low-field H-13 and H-13' doublets of the exomethylene group, as well as brs of the

7 hydroperoxy group, and the appearance of quintet of $\mathrm{H}-11(\delta 2.74, J=7.6 \mathrm{~Hz})$ and doublet of

8 Me-13 $(\delta 1.19, J=7.6 \mathrm{~Hz})$ were the main distinctions of ${ }^{1} \mathrm{H}$ NMR spectrum of $\mathbf{2}$, in comparison

9 with 1 . It is very possible that the lactone 2 (3,9-diacetoxy-1-hydroxy- $6 \beta, 7 \alpha, 11 \mathrm{H}$-germacra-

$104,10(14)$-dien-12,6 $\alpha$-olide) was formed from sintenin, via corresponding 1,10-epoxy derivative.

11 The hydroperoxide 1 and sintenin might have the same precursor, most probably costunolide or 12 corresponding mono- or di-acetoxy derivative.

\section{Table 1}

16 Molecular formula $\mathrm{C}_{18} \mathrm{H}_{22} \mathrm{O}_{7}$ for lactone 3 was concluded from HRESI mass spectrum, recorded

17 in the positive-ion mode, using ammonium formiate for the ionisation $\left(\left[\mathrm{M}+\mathrm{NH}_{4}\right]^{+}\right.$at $\mathrm{m} / \mathrm{z}$

18368.17165 , calc. 368.17038; [M+Na $]^{+}$at $\mathrm{m} / \mathrm{z}$ 373.12752, calc. 373.12577). In EI mass spectrum,

19 ions $[\mathrm{M}]^{+}(\mathrm{m} / \mathrm{z} 350),[\mathrm{MH}-\mathrm{HOAc}]^{+}(\mathrm{m} / \mathrm{z} 290)$ and $[\mathrm{MeC}=\mathrm{O}]^{+}(\mathrm{m} / \mathrm{z} 43)$ were discerned, which

20 implied the presence of an acetoxy group and the methyl ketone group. The IR spectrum revealed

21 four carbonyls with absorption bands at $1765 \mathrm{~cm}^{-1}$ ( $\gamma$-lactone), $1749 \mathrm{~cm}^{-1}$ (OAc), $1733 \mathrm{~cm}^{-1}$

$22(\mathrm{C}=\mathrm{O})$ and $1708 \mathrm{~cm}^{-1}(\mathrm{C}=\mathrm{O})$. In the ${ }^{1} \mathrm{H}$ NMR spectrum (Table 1) characteristic doublets for $\alpha$ -

23 methylene- $\gamma$-lactone group $(\mathrm{H}-13: \delta 6.40, J=2.6 \mathrm{~Hz} ; \mathrm{H}-13$ ' $: \delta 5.67, J=2.0 \mathrm{~Hz})$ and a multiplet 
1 of H-7 ( $\delta 3.19)$ were present. These protons, coupled with each other, were a part of one of the

2 two spin systems recognized in TOCSY spectrum (Fig. 3). Besides $\mathrm{H}_{2}-13$ and $\mathrm{H}-7$, this system

3 included $\mathrm{H}-6(\delta 5.06 d, J=4.6 \mathrm{~Hz}), \mathrm{H}_{2}-8(\delta 2.09 t, J=7.0 \mathrm{~Hz})$ and $\mathrm{H}-9(\delta 5.13 t, J=6.8 \mathrm{~Hz}), \mathrm{a}$

4 low-field proton geminal to an acetoxy group. A singlet of OAc was partly overlapped $(\delta 2.15-$

5 2.17) with singlets of two methyl groups bound to $\mathrm{sp}^{2}$-carbons. One of these signals was assigned

6 to Me-14 at carbonyl C-10 and the other to Me-15 at olefinic C-4 (double bound to C-5). The

7 multiplicity of H-6 indicated C-5 to be quarternary. These data, together with the evidence about

8 the existence of separated ABX spin system of five-membered ring, indicated iso-seco-

9 guaianolide structure of 3. ABX system was constituted of diastereotopic $\mathrm{CH}_{2}-2$ group (A: $\delta 2.70$

$\left.10 d d\left(J_{1}=6.2 \mathrm{~Hz}, J_{2}=18.4 \mathrm{~Hz}\right), \mathrm{B}: \delta 2.34 d d\left(J_{1}=2.2 \mathrm{~Hz}, J_{2}=18.4 \mathrm{~Hz}\right)\right)$ and a proton H-3 $(\mathrm{X}: \delta$

$114.31 \mathrm{brd}(J=4.8 \mathrm{~Hz}))$ geminal to OMe group $(\delta 3.42 s)$. Therefore, 3 is 9-acetoxy-3-O-methyl-

12 iso-seco-tanapartholide. In NOESY spectrum, more or less expected correlations which confirm

13 the former structure appeared: $\mathrm{H}_{2}-8 / \mathrm{H}-13^{\prime}, \mathrm{H}-9, \mathrm{H}-6, \mathrm{OAc}, \mathrm{H}-7$; H-2/H-2', H-3, OMe; H-2'/H-2,

$14 \mathrm{H}-3 ; \mathrm{H}-7 / \mathrm{H}-13^{\prime}, \mathrm{H}-6$. Because of the remote nature of the C-3 stereocenter and the flexibility of

15 the (C-8)-(C10) fragment, there was not an evidence about stereochemistry at C-3 and C-9. The

16 configuration at C-9 was deduced on the basis of the previous findings that seco-guaianolides,

17 endo-peroxyguaianolides and bis-epoxy-guaianolides were biosinteticaly related: all derived from

18 common cyclopentadiene precursors; seco- and iso-seco-guaianolides formed by a cleavage of

19 (C-1)-(C-10) bond of corresponding epoxy-guaianolides [20]. Accordingly, 9(R)-configuration of

203 is proposed, as compatible with $9 \alpha$-position of acetoxy group of presented endoperoxide 4 and

21 bis-epoxide 5.

22 Seco-guaianolides and iso-seco-guaianolides mainly occurred in the genera Artemisia, Tanacetum

23 and Achillea. Iso-seco-tanapartholide, firstly isolated from Artemisia rutifolia in 1986 [21], has 
1 recently been identified in Tanacetum parthenium, together with its 3 -epimer $(3 \alpha-\mathrm{OH})$, and

2 afterwards both were synthesized. A little difference in NMR data of two epimers and unequal

3 optical rotations were exploited for the comprehensive stereochemical revision of previously

4 isolated 'iso-seco-tanapartholides' from different plants [22]. Epi-iso-seco-tanapartholide was

5 recognized as a major product in some Achillea species.

6 Reviewing literature for 3-epimers of 3-O-methyl-iso-seco-tanapartholides we could not find

7 strong evidence for its distinction $[11,23,24]$. Therefore, we gave up resolving C-3 configuration

8 on the basis of comparing our data with existing spectroscopic data. As well as in the case of $i s o-$

9 seco-tanapartholides, synthesis of these epimeric compounds is essential for their complete

10 characterization and also required for a revision of the preceding literature data.

\section{$12 \quad$ Fig. 3}

14 The guianolide 5 was easily determined as $9 \alpha$-acetoxycanin due to the similarity of its spectral

15 data with those of the previously isolated diastereomer $9 \alpha$-acetoxyartecanin from the same plant

16 [9]. $9 \alpha$-Acetoxycanin was also found in A. depressa [11]. In the previous study of $1 \mathrm{D}$ and 2D

17 NMR data of eleven 1,2-epoxy- and 1,2:3,4-diepoxy-guianolides, which we had isolated from

18 different Achillea species, we noted a relation between the chemical shifts of $\mathrm{C}(\mathrm{H})-5$ fragment

19 and the configuration of the 1,2-epoxy ring [25]. Briefly, a signal of H-5 (vicinal to the epoxide)

20 of $1 \alpha, 2 \alpha$-epoxyguaianolides is shielded, while $\mathrm{C}-5$ is deshielded in comparison with

21 corresponding data of appropriate $\beta$-epoxy-diastereomers. Here, signals of $\mathrm{H}-5$ and $\mathrm{C}-5$ of 5

22 appeared at $\delta 2.65$ and $\delta 50.6$, respectively, while the signals of its bis- $\beta$-epoxy-diastereomer $9 \alpha$ - 
1 acetoxyartecanin were noticed at $\delta_{\mathrm{H}} 2.87$ and $\delta_{\mathrm{C}} 43.0$ [9], which is one more confirmation of the

2 mentioned, previously recognized spectral rule for this type of compounds.

3

4 For testing the in vitro cytotoxicity of $A$. clavennae sesquiterpenoids, we have selected the

5 predominant metabolite germacranolide sintenin (6), lactone apressin (4) and the new iso-seco-

6 guaianolide (3). The glioma cell lines C6 and U251 were chosen as targets, having in mind that

7 gliomas, the most common primary malignancy of the central nervous system, are extremely

8 aggressive and mostly incurable tumors [26]. The treatment with compound 6 for $24 \mathrm{~h}$ had no

9 significant influence on either mitochondrial respiration or numbers of glioma cells (Fig. 4),

10 which is consistent with previous results obtained in various cancer cell lines [27, 28]. Compound

114 was toxic to all tested cells, including primary astrocytes (Fig. 4), which is in accordance with

12 the earlier reports [9]. The new iso-seco-guaianolide (3) also displayed a significant dose-

13 dependent cytotoxicity towards glioma cells, as determined both by MTT assay for mitochondrial

14 respiration and crystal violet test for cell numbers (Fig. 4). The analysis of the $\mathrm{IC}_{50}$ values

15 presented in Table $\mathbf{2}$ indicates that compound $\mathbf{3}$ was significantly more active against glioma

16 cells than compound 4, but somewhat less efficient than the prototypical anticancer drug

17 cisplatin. Importantly, unlike compound $\mathbf{4}$ and cisplatin, compound $\mathbf{3}$ displayed only a limited

18 toxicity towards rat primary astrocytes (Fig. 4). While this could be due to a lower proliferation

19 rate of primary astrocytes, it nevertheless indicates that transformed glial cells might be more

20 selective to compound $\mathbf{3}$ than their primary counterparts.

22 Fig. 4

23 Table 2 
2 After confirming the in vitro antiglioma action of compound $\mathbf{3}$, we next assessed its ability to

3 induce programmed cell death known as apoptosis. We first examined activation of caspases, the

4 main apoptosis-executing enzymes [29], using fluorescent-labeled pan-caspase inhibitor ApoStat

5 (Fig. 5A). Flow cytometric analysis revealed that compound 3 induced a dose- dependent caspase

6 activation in both C6 and U251 glioma cells. Furthermore, the cell cycle analysis after PI staining

7 of cellular DNA demonstrated that the exposure to compound 3 increased the numbers of

8 hypodiploid glioma cells with fragmented DNA (sub-G0/G1 compartment) (Fig. 5B), which is a

9 hallmark of apoptosis [30]. Annexin-detectable externalization of phosphatidylserine is another

10 apoptotic marker [31], and the treatment with compound $\mathbf{3}$ increased the numbers of annexin

11 glioma cells displaying phosphatidylserine in the outer leaflet of cell membrane (Fig. 5C). The

12 effects of compound $3(25 \mu \mathrm{M})$ on DNA fragmentation (21.5\% hypodiploid cells) and

13 phosphatidylserine exposure $\left(32.8 \%\right.$ annexin $^{+}$cells $)$in U251 cells were only slightly less

14 prominent than those of cisplatin at the same concentration $(32.4 \%$ and $37.8 \%$, respectively; data

15 not shown). These results clearly demonstrate that compound $\mathbf{3}$ induces apoptotic death of glioma

16 cells. However, it should be noted that compound $\mathbf{3}$ also increased the proportion of $\mathrm{PI}^{+}$cells with

17 the cell membrane damage (Fig. 5C), which could be late apoptotic and/or necrotic cells.

18 Therefore, the possibility that compound $\mathbf{3}$ could actually induce mixed apoptotic/necrotic death

19 requires further investigation.

21 Fig. 5

23 Oxidative-stress mediated mitochondrial dysfunction can lead to activation of caspases and 24 subsequent apoptotic cell demise [31]. Thus, we next examined the effects of compound 3 on 
1 ROS production and mitochondrial membrane potential in glioma cells. The flow cytometric 2 analysis of cells stained with the redox-sensitive dye DHR demonstrated that compound 3 was 3 able to induce a dose- dependent ROS generation in glioma cell lines (Fig. 6A). The induction of 4 oxidative stress in compound 3-treated C6 glioma cells was associated with the mitochondrial 5 membrane depolarization, as confirmed by the increase in green-to-red fluorescence ratio 6 (FL1/FL2) of the mitochondria-binding dye DePsipher (Fig. 6B). While these data indicate that 7 oxidative stress and subsequent mitochondrial depolarization are involved in the cytotoxicity of 8 compound $\mathbf{3}$, this assumption remains to be directly confirmed.

12 The previously isolated structurally related iso-seco-guaianolides were found to reduce viability 13 of immortalized human keratinocytes [32] and inhibit nitric oxide synthesis in 14 lipopolysaccharide-activated RAW 264.7 cells [33], probably through interaction with NF- $\kappa$ B 15 signaling pathway [22]. The high biological activities of these compounds, including new iso16 seco-guaianolide 3 , are most likely connected with their $\alpha, \beta$-unsaturated carbonyl electrophilic 17 groups: an $\alpha$-methylene- $\gamma$-lactone and an $\alpha, \beta$-unsaturated cyclopentenone. These groups are 18 known to mediate a Michael-type addition reaction with thiol-containing enzymes and proteins. 19 The importance of these structural features is primarily supported by the fact that lactone 6 20 (without mentioned groups) was inactive in the present study. Accordingly, lactone 4 with only 21 one $\alpha, \beta$-unsaturated carbonyl group was less active than $\mathbf{3}$.

22 Taken together, our data for the first time demonstrate that compound 3, a novel iso-seco23 tanapartholide from $A$. clavennae, triggers apoptotic death of glioma cells associated with the 24 induction of oxidative stress and mitochondrial depolarization. 
2 Materials and methods

3

$4 \quad$ General experimental procedures

5 Optical rotations were determined on a Rudolph Research Analytical automatic polarimeter, 6 Autopol IV. IR spectra were measured in the form of transparent films on a Perkin-Elmer FT-IR 7 spectrometer $1725 \mathrm{X} .{ }^{1} \mathrm{H}$ and ${ }^{13} \mathrm{C}$ NMR spectra were recorded on a Varian Gemini 2000 (at 200 8 and $50 \mathrm{MHz}$, respectively) and an Bruker Avance III spectrometer (at 500 and $125 \mathrm{MHz}$, 9 respectively) in $\mathrm{CDCl}_{3}$, using TMS as internal standard. Mass spectra were obtained on a 10 Finnigan MAT 8230, BE DCI (150 eV, iso-butane). High-resolution LC/ESI TOF mass spectra 11 were measured on a HPLC instrument (Agilent 1200 Series) with a Zorbax Eclipse Plus C18 12 column $(150 \times 4.6 \mathrm{~mm}$ i.d.; $1.8 \mu \mathrm{m})$ and a diode-array detector (DAD) coupled with a 6210 time13 of-flight LC/MS system (Agilent Technologies). Elemental analysis was performed on a Vario 14 EL III C,H,N,S/O Elemental Analyzer (Elementar). CC was carried out on silica gel 60 (0.063$150.200 \mathrm{~mm}$, Merck). Preparative TLC was performed on silika gel $\mathrm{G}$ and $\mathrm{F}_{254}(0.75 \mathrm{~mm}$ layer, $20 \times$ $1620 \mathrm{~cm})$. Silica gel $60 \mathrm{~F}_{254}$ precoated aluminum sheets $(0.25 \mathrm{~mm}$, Merck) were used for TLC 17 control. Spots were detected under UV254 and by spraying with $50 \% \mathrm{H}_{2} \mathrm{SO}_{4}$.

19 Plant material

20 The aerial parts of Achillea clavennae L. (Asteraceae) were collected at the flowering stage in 21 July 2002 in Montenegro at the mountain Prokletije (Karanfili, altitude ca. 2000 m). The plant 22 sample was identified by Prof. Pedja Janaćković (Faculty of Biology, University of Belgrade, 
1 Belgrade, Serbia), and a voucher specimen (BEOU16677) was deposited in the BEOU-

2 Herbarium, Institute of Botany, Faculty of Biology (Belgrade, Serbia).

3

4 Extraction and isolation

5 The air-dried aerial parts of $A$. clavennae $(270 \mathrm{~g})$ were extracted at a room temperature with a

6 mixture of petrol- $\mathrm{Et}_{2} \mathrm{O}-\mathrm{MeOH}(1: 1: 1,2.1 \mathrm{~L}, 24 \mathrm{~h})$ using the standard procedure [34]. The initial

7 extract $(9.0 \mathrm{~g})$ was treated with $\mathrm{MeOH}(3 \times 50 \mathrm{~mL})$ to yield $7.2 \mathrm{~g}$ of $\mathrm{MeOH}$ soluble portion.

8 Further fractionation was carried out on silica gel dry-column flash chromatography $(250 \mathrm{~g}, 10 \times$

$914 \mathrm{~cm}$ ), starting the elution with petrol (fraction $\mathbf{F 1}, 400 \mathrm{~mL}$ ) and increasing polarity by adding

$10 \mathrm{Et}_{2} \mathrm{O}(20 \%$ to $100 \%, \mathbf{F 2}-\mathbf{F 1 0}, 350 \mathrm{~mL}$ each $)$ and $\mathrm{MeOH}(15 \%, \mathbf{F 1 1}, 350 \mathrm{~mL})$. Fractions were

11 evaporated, and $\mathbf{F} 7$ (petrol- $\mathrm{Et}_{2} \mathrm{O} 3: 7,423 \mathrm{mg}$ ) and $\mathbf{F 8}$ (petrol- $\mathrm{Et}_{2} \mathrm{O}$ 2:8, $441 \mathrm{mg}$ ) were combined

12 after inspection of analytical TLC $\left(\mathrm{CH}_{2} \mathrm{Cl}_{2}-\mathrm{MeOH} 97: 3\right)$ and ${ }^{1} \mathrm{H}$ NMR spectra of all fractions.

13 F6 (petrol- $\mathrm{Et}_{2} \mathrm{O}$ 4:6, $\left.558 \mathrm{mg}\right)$ was chromatographed on silica gel $\mathrm{CC}(300 \mathrm{~g}, 45 \times 3.5 \mathrm{~cm}$;

$\left.14 \mathrm{CH}_{2} \mathrm{Cl}_{2}-\mathrm{MeOH} 97: 3\right)$ to yield 48 subfractions ( $20 \mathrm{~mL}$ each). Fractions 7-12 (F6a, $\left.62.4 \mathrm{mg}\right), 22$

15 (F6b, $24.1 \mathrm{mg}$ ), and 25-29 (F6c, $51.0 \mathrm{mg}$ ) were further purified by preparative TLC. Sesamin (3.2

$16 \mathrm{mg}, \mathrm{F} 6 \mathrm{a} / \mathrm{CH}_{2} \mathrm{Cl}_{2}-\mathrm{MeOH}$ 97.5:2.5), apressin $\left(4,3.5 \mathrm{mg}, \mathrm{F} 6 \mathrm{~b} / \mathrm{CH}_{2} \mathrm{Cl}_{2}-\mathrm{MeOH}\right.$ 97:3) and oleanolic

17 acid (7, $2.1 \mathrm{mg}, \mathrm{F} 6 \mathrm{c} / \mathrm{CH}_{2} \mathrm{Cl}_{2}-\mathrm{MeOH}$ 97.5:2.5, repeated prep.TLC) were obtained.

$18 \quad \mathbf{F 7}+\mathbf{8}(864 \mathrm{mg})$ was divided into 75 subfractions $(\sim 30 \mathrm{~mL}$ each) by silica gel CC $(430 \mathrm{~g}, 70 \times 3.5$

$19 \mathrm{~cm})$ gradually increasing polarity of eluent $\left(\mathrm{CH}_{2} \mathrm{Cl}_{2}-\mathrm{MeOH}, 97.4: 2.6-96: 4\right)$. Subfr. $\mathrm{F} 7 \mathrm{a}(23-26$,

$2036.6 \mathrm{mg})$, F7b $(27-33,74.2 \mathrm{mg}), \mathrm{F} 7 \mathrm{c}(34-49,102.1 \mathrm{mg}), \mathrm{F} 7 \mathrm{~d}(54-57,32.3 \mathrm{mg})$, and F7e (71-75,

$21 \quad 56.2 \mathrm{mg}$ ) were purified by preparative TLC (always at several plates). Lactone $2(1.1 \mathrm{mg})$ was

22 isolated from F7a and lactone apresin $(4,10.9 \mathrm{mg})$ from $\mathrm{F} 7 \mathrm{~b}$ with the same solvent system

$23\left(\mathrm{CH}_{2} \mathrm{Cl}_{2}-\mathrm{MeOH}\right.$ 96.5:3.5). Lactone 3 (5.4 mg) was obtained from $\mathrm{F} 7 \mathrm{c}\left(\mathrm{CH}_{2} \mathrm{Cl}_{2}-\mathrm{MeOH}\right.$ 97:3). 11-

24 Dehydroxy,11-hydroperoxyindicumenone $(1.4 \mathrm{mg})$ was obtained from $\mathrm{F} 7 \mathrm{~d}$ together with 
1 additional $1.1 \mathrm{mg}$ of $\mathbf{3}\left(\mathrm{CH}_{2} \mathrm{Cl}_{2}-\mathrm{MeOH}\right.$ 96.5:2.5, repeated TLC). Chrysetunone (0.5 mg) and 2 centaureidin (1.4 mg) were isolated from $\mathrm{F} 7 \mathrm{e}\left(\mathrm{CH}_{2} \mathrm{Cl}_{2}-\mathrm{MeOH} 97: 3\right)$.

3 Silica gel CC (300 g, $\left.45 \times 3.5 \mathrm{~cm} ; \mathrm{CH}_{2} \mathrm{Cl}_{2}-\mathrm{MeOH} 97: 3\right)$ of $\mathbf{F 9}$ (petrol- $\mathrm{Et}_{2} \mathrm{O}$ 1:9, $495 \mathrm{mg}$ ) yielded 440 subfractions ( $\sim 30 \mathrm{~mL}$ each), which were combined after analytical TLC. F9a (4-5, 37.5 mg) 5 yielded lactones $4(8.5 \mathrm{mg}), \mathbf{1}(1.4 \mathrm{mg})$, and $\mathbf{6}(1.0 \mathrm{mg})$ after repeated preparative TLC (solvent 6 system $\mathrm{CH}_{2} \mathrm{Cl}_{2}-\mathrm{MeOH}$ 97:3). $\mathrm{F9b}\left(6-7,28.2 \mathrm{mg}\right.$ ) was washed out with $\mathrm{Et}_{2} \mathrm{O}$ and an insoluble 7 portion was crystallized from $\mathrm{CH}_{2} \mathrm{Cl}_{2}$ giving $11.4 \mathrm{mg}$ of sintenin (6). $9 \alpha$-Acetoxycanin (5, 0.9 $8 \mathrm{mg})$ was isolated from F9c (13-16, 33.1 mg) after repeated preparative TLC with solvent systems 9 toluen-Et ${ }_{2} \mathrm{O}-\mathrm{MeOH}(7: 2: 1)$ and $\mathrm{CH}_{2} \mathrm{Cl}_{2}-\mathrm{MeOH}(97: 3)$.

10 Lactone sintenin $(10.0 \mathrm{mg})$ was also isolated from $\mathbf{F 1 0}\left(\mathrm{Et}_{2} \mathrm{O}, 450 \mathrm{mg}\right)$, which was firstly divided 11 into 20 subfractions $(\sim 30 \mathrm{~mL}$ each $)$ by silica gel $\mathrm{CC}(280 \mathrm{~g}, 40 \times 3.5 \mathrm{~cm})$ using solvent system $12 \mathrm{CH}_{2} \mathrm{Cl}_{2}-\mathrm{MeOH}(97: 3)$. From combined fraction 4-8 $(65.3 \mathrm{mg})$, this compound was separated as 13 insoluble in $\mathrm{Et}_{2} \mathrm{O}$.

16 Yellowish gum; $[\alpha]_{\mathrm{D}}^{22}+30.2\left(\mathrm{CH}_{2} \mathrm{Cl}_{2}, c\right.$ 0.119); CIMS (iso-butane, probe), $150 \mathrm{eV}, \mathrm{m} / z$ (rel.

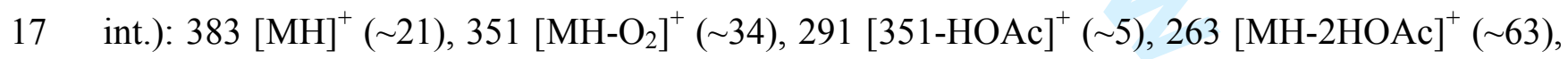
$18245 \quad\left[263-\mathrm{H}_{2} \mathrm{O}\right]^{+} \quad(\sim 68) ; \quad H R E S I M S: \quad m / z \quad 381.15398 \quad[\mathrm{M}+\mathrm{H}]^{+}$(calculated for $\mathrm{C}_{19} \mathrm{H}_{24} \mathrm{O}_{8}+\mathrm{H}$ 19 381.15439); ${ }^{1} \mathrm{H}$ and ${ }^{13} \mathrm{C}$ NMR data, see Table 1; COSY and NOESY data, see Fig. 2; HMBC: $\mathrm{H}_{3-}$ 20 15/C-3, C-4, C-5; H2-14/C-9; H-14/C-10; H-13/C-7, C-11; H-3/C-5.

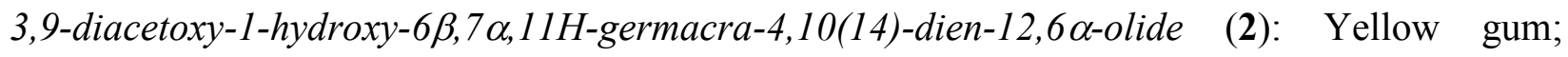
$23[\alpha]_{D}^{22}+24.0\left(\mathrm{CH}_{2} \mathrm{Cl}_{2}, c 0.101\right)$; CIMS (iso-butane, probe), $150 \mathrm{eV}, \mathrm{m} / z$ (rel. int.): $367[\mathrm{MH}]^{+}$ 


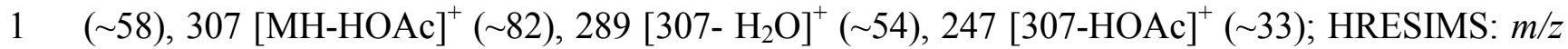

$2367.17513[\mathrm{M}+\mathrm{H}]^{+}$(calculated for $\mathrm{C}_{19} \mathrm{H}_{26} \mathrm{O}_{7}+\mathrm{H} 367.17485$ ); ${ }^{1} \mathrm{H}$ NMR data, see Table 1.

3

4 9(R)-acetoxy-3-O-methyl-iso-seco-tanapartholide (3): White crystals; $[\alpha]_{\mathrm{D}}^{22}-10.7\left(\mathrm{CH}_{2} \mathrm{Cl}_{2}, c\right.$

5 0.168); IR $v_{\max }^{\text {flm }}\left(\mathrm{cm}^{-1}\right): 1765$ ( $\gamma$-lactone), $1749(\mathrm{OAc}), 1733(\mathrm{C}=\mathrm{O}), 1708(\mathrm{C}=\mathrm{O}) ;{ }^{1} \mathrm{H}$ and ${ }^{13} \mathrm{C}$

6 NMR data, see Table 1; HMBC: $\mathrm{H}_{2}-8 / \mathrm{C}-9, \mathrm{C}-11$, $\mathrm{OCOCH}_{3} ; \mathrm{OMe} / \mathrm{C}-3$; H-13/C-11; TOCSY data,

7 see Fig. 3; NOESY: H2-8/H-13', H-9, H-6, OAc, H-7; H-2/H-2', H-3, OMe; H-2'/H-2, H-3, OMe;

8 H-7/H-13', H-6; EIMS (70 eV), m/z: $350[\mathrm{M}]^{+}, 290[\mathrm{M}-\mathrm{HOAc}]^{+}, 247\left[290-\mathrm{COCH}_{3}\right]^{+}, 215[247-$

$\left.9 \quad \mathrm{HOCH}_{3}\right]^{+}$; HRESIMS: $m / z$ 368.17165 $\left[\mathrm{M}+\mathrm{NH}_{4}\right]^{+}$(calculated for $\mathrm{C}_{18} \mathrm{H}_{22} \mathrm{O}_{7}+\mathrm{NH}_{4}$ 368.17038) and

$10 \mathrm{~m} / z$ 373.12752 [M+Na] ${ }^{+}$(calculated for $\mathrm{C}_{18} \mathrm{H}_{22} \mathrm{O}_{7}+\mathrm{Na} 373.12577$ ); Elemental analysis: found $\mathrm{C}$ -

11 61.60, $\mathrm{H}-6.42$; requires: $\mathrm{C}-61.71, \mathrm{H}-6.33 \%$.

12

13 Cells and reagents

14 All reagents were from Sigma-Aldrich (St. Louis, MO) unless stated otherwise. Human glioma 15 cell line U251 and rat glioma cell line C6 were kindly donated by Dr Pedro Tranque (Universidad 16 de Castilla-La Mancha, Albacete, Spain). The primary astrocytes were isolated from brains of 17 newborn Albino Oxford rats as previously described [35], in accordance with the ethical 18 guidelines stated in the "Principles of Laboratory Animal Care" (NIH publication \#85-23, revised 19 in 1985). Tumor cell lines and primary rat astrocytes were grown in HEPES (20 mM)-buffered 20 RPMI 1640 cell culture medium, supplemented with 5\% fetal bovine serum, 2 mM L-glutamine, $2110 \mathrm{mM}$ sodium pyruvate and $1 \%$ of antibiotic/antimycotic mixture at $37{ }^{\circ} \mathrm{C}$ in a humidified 22 atmosphere with $5 \% \mathrm{CO}_{2}$. The cells were prepared for experiments using trypsin/EDTA and 23 incubated in 96-well flat-bottom cell culture plates $\left(2 \times 10^{4}\right.$ cells/well $)$ for the cell viability 
1 assessment, or 6 -well plates $\left(5 \times 10^{5}\right.$ cells/well) for the flow cytometric analysis (plates were

2 from Sarstedt, Nümbrecht, Germany). Cells were rested for $24 \mathrm{~h}$ and then treated with

3 compounds 3, 4 and 6. Purity of 3, 4 and 6 was confirmed by elemental analysis (>99\%). Control

4 cultures were exposed to the corresponding amount of vehicle (DMSO). We observed no

5 influence of DMSO on any of the parameters tested (data not shown). Cisplatin ( $\geq 99.9 \%$,

6 Sigma-Aldrich), a well known anticancer drug was used in some experiments as a positive

7 control. Incubation times and concentrations of compounds are stated in figure legends.

9 Cell viability

10 Mitochondrial dehydrogenase activity, as an indicator of cell viability, was assessed by 11 mitochondria-dependent reduction of 3-(4,5-dimethylthiazol-2-yl)-2,5-diphenyltetrazolium

12 bromide (MTT) to formazan, and the number of viable cells was determined using crystal violet 13 assay, exactly as previously described [36]. The MTT and crystal violet absorbance was 14 measured in an automated plate reader (Sunrise, Tecan, Dorstet, UK) at $570 \mathrm{~nm}$. The $\mathrm{IC}_{50}$ values 15 were calculated using GraphPad Prism software.

17 Caspase activation

18 Activation of caspases was measured using cell-permeable FITC-conjugated pan-caspase 19 inhibitor ApoStat (R\&D Systems, Minneapolis, MN), according to manufacturer's instructions.

20 The increase in green fluorescence (FL1) as a measure of caspase activity was detected using 21 FASCalibur flow cytometer (BD, Heidelberg, Germany). The results are presented as mean 22 intensity of ApoStat fluorescence.

24 Apoptosis analysis 
1 DNA fragmentation as a marker of apoptotic cell death was analyzed by measuring the DNA

2 content of ethanol-fixed cells stained with DNA-binding dye propidium iodide (PI), exactly as

3 previously described [36]. Red (FL2) fluorescence of PI-stained cells was measured, and

4 percentage of hypodiploid, apoptotic cells (sub-G compartment of the cell cycle) was determined.

5 Alternatively, apoptotic cell death was assessed after double staining with annexinV-FITC and

6 PI, according to manufacturer's instructions (BD, Heidelberg, Germany). Annexin binds the

7 phosphatidylserine exposed on the membrane of apoptotic cells, while PI labels the DNA in cells

8 with membrane damage. The green (FL1) and red (FL2) fluorescence of annexinV-FITC/PI

9 labeled cells was analyzed, and annexin $/ \mathrm{PI}^{-}$and annexin ${ }^{+} / \mathrm{PI}^{+}$cells were considered as early and

10 late apoptotic cells, respectively. Flow cytometry analyses were conducted on FACSCalibur flow

11 cytometer using CellQuest Pro software (BD, Heidelberg, Germany).

13 Determination of oxidative stress and mitochondrial membrane potential

14 Intracellular production of reactive oxygen species (ROS) was determined using redox-sensitive 15 fluorescent dye dihydrorhodamine 123 (DHR; Invitrogen, Paisley, UK). DHR (5 $\mu \mathrm{M})$ was added 16 to cell cultures at the beginning of the treatment. The mean intensity of green (FL1) fluorescence 17 corresponding to oxidative stress was determined using FACSCalibur flow cytometer. 18 Mitochondrial membrane potential was determined using DePsipher (R\&D Systems), a lipophilic 19 cation that has the property of aggregating upon membrane polarization forming an orange-red 20 fluorescent compound. If the potential is disturbed the dye remains or reverts to its green 21 monomeric form. The cells were stained with DePsipher as described by the manufacturer and 22 fluorescence was detected by flow cytometry. The results are presented as green/red fluorescence 23 ratio (mean FL1/FL2), the increase of which reflects mitochondrial depolarization. 
1

2

3

4

5

6

7

8

9

10

11

12

13

14

15

16

17

18

19

20

21

22

23

24

25

26

27

28

29

30

31

32

33

34

35

36

37

38

39

40

41

42

43

44

45

46

47

48

49

50

51

52

53

54

55

56

57

58

59

60

\section{Acknowledgements}

2 This study was financially supported by the Serbian Ministry of Education, Science and 3 Technological Development (Grant No. 172053 and 41025).

4

5 Conflict of Interest

6 There are no conflicts of interest.

7

8

9 


\section{$1 \quad$ References}

2 1. Gajić M. Genus Achillea L. In: Josifović VM, editor. Flora of Serbia VII. Belgrade: Serbian

3 Academy of Sciences and Arts; 1975: 90-110

4 2. Trifunović SS. Comparative investigation of the chemical composition of some plant species

5 of the genus Achillea L. [dissertation]. University of Belgrade: Faculty of Chemistry; 2006

6 3. Sia XT, Zhanga ML, Shi QW, Kiyota H. Chemical constituents of the plants in the genus

$7 \quad$ Achillea. Chem Biodivers 2006; 3: 1163-1180

8 4. Valant-Vetschera KM, Wollenweber E. Exudate flavonoid aglycones in alpine species of $9 \quad$ Achillea sect. Ptarmica. Biochem Syst Ecol 2001; 29: 149-159

10 5. Maggioni G. Nicolò Chiavenna, Bellunese druggist of the sixteenth century and the contested 11 discovery of umbelliferous absinthium (Achilea clavenae L.). Minerva Farm 1953; 2: 267-269

12 6. Skočibušić M, Bežić N, Dunkić V, Radonić A. Antibacterial activity of Achillea clavennae

13 essential oil against respiratory tract pathogens. Fitoterapia 2004; 75: 733-736

14 7. Bežić N, Skočibušić M, Dunkić $V$, Radonić A. Composition and antimicrobial activity of 15 Achillea clavennae L. essential oil. Phytother Res 2003; 17: 1037-1040

16 8. Stojanović $G$, Radulović $N$, Hashimoto $T$, Palić $R$. In vitro antimicrobial activity of extracts of

17 four Achillea species: the composition of Achillea clavennae L. (Asteraceae) extract. J 18 Ethnopharmacol 2005; 101: 185-190

19 9. Trifunović S, Vajs V, Juranić Z, Žižak Ž, Tě̌ević V, Macura S, Milosavljević S. Cytotoxic 20 constituents of Achillea clavennae from Montenegro. Phytochemistry 2006; 67: 887-893

21 10. Tsankova E, Kempe UJ, Norin T, Ognyanov I. Apressin, a guaianolide of the endoperoxide 22 type from Achillea depressa. Phytochemistry 1981; 20: 1436-1438

23 11. Todorova M, Mustakerova E, Tsankova E. Sesquiterpene lactones from Achillea depressa 24 Janka. Dokladi na Bulgarskata Akademiya na Naukite 2005; 58: 25-32 
1 12. Goren N, Oksuz S, Ulubelen A. A Sesquiterpene Lactone, Sintenin from Achillea sintenisii. $2 \quad$ Phytochemistry $1988 ; 27: 2346-2347$

3 13. Mladenova K, Tsankova E, van Hung D. New sesquiterpenoids from Chrysanthemum $4 \quad$ indicum var. tuneful. Planta Med 1988; 54: 553-555

5 14. Meselhy MR. Constituents from Moghat, the Roots of Glossostemon bruguieri (Desf.). $6 \quad$ Molecules 2003; 8: 614-621

7 15. Long C, Sauleau P, David B, Lavaud C, Cassabois V, Ausseil F, Massiot G. Bioactive 8 flavonoids of Tanacetum parthenium revisited. Phytochemistry 2003; 64: 567-569

9 16. Seebacher $W$, Simić $N$, Weis $R$, Saf R, Kunert $O$. Complete assignments of ${ }^{1} \mathrm{H}$ and ${ }^{13} \mathrm{C}$ NMR 10 resonances of oleanolic acid, 18 $\alpha$-oleanolic acid, ursolic acid and their 11-oxo derivatives. $11 \quad$ Magn Reson Chem 2003; 41: 636-638

12 17. Oksuz S, Ulubelen A, Tuzlaci E. Constituents of Achillea teretifolia. Fitoterapia 1990; 61: 283

13 18. Barrero AF, Alvarez-Manzaneda REJ, Alvarez-Manzaneda RR. Bisabolene derivatives and 14 other constituents from Achillea odorata. Phytochemistry 1990; 29: 3213-3216

15 19. Bruno M, Bondi ML, Paternostro MP, Arnold NA, Diaz JG, Herz W. Bisabolenes from $16 \quad$ Achillea cretica. Phytochemistry 1996; 42: 737-740

17 20. Hewlett MJ, Begley MJ, Groenewegen WA, Heptinstall S, Knight DW, May J, Salan U, Toplis

18 D. Sesquiterpene lactones from feverfew, Tanacetum parthenium: isolation, structural 19 revision, activity against human blood platelet function and implications for migraine therapy. 20 J Chem Soc Perkin Trans I. 1996; 16: 1979-1986

21 21. Huneck S, Zdero C, Bohlmann F. Seco-guaianolides and other constituents from Artemisia $22 \quad$ species. Phytochemistry 1986; 25: 883-889 
1 22. Makiyi EF, Frade RFM, Lebl T, Jaffray EG, Cobb SE, Harvey AL, Slawin AMZ, Hay RT,

2 Westwood NJ. Iso-seco-tanapartholides: Isolation, Synthesis and Biological Evaluation. Eur.

$3 \quad$ J. Org. Chem. 2009; 33: 5711-5715

4 23. Tan RX, Jia ZJ, Jakupovic J, Bohlmann F, Huneck S. Sesquiterpene lactones from Artemisia

$5 \quad$ rutifolia. Phytochemistry 1991; 30: 3033-3035

6 24. Zan K, Chen X-Q, Fu Q, Shi S-P, Zhou S-X, Xiao M-T, Tu P-F. 10-Secoguaianolides from

7 Artemisia anomala (Asteraceae). Biochemical Systematics and Ecology 2010; 38: 431-434

8 25. Trifunović S, Milosavljević S, Vajs $V$, Macura S, Todorović $N$. Stereochemistry and 9 conformations of natural 1,2-epoxy-guaianolides based on 1D and 2D NMR data and 10 semiempirical calculations. Magn Reson Chem 2008; 46: 427-431

11 26. Giese A, Bjerkvig R, Berens ME, Westphal M. Cost of migration: invasion of malignant 12 gliomas and implications for treatment. J Clin Oncol 2003; 21: 1624-1636

13 27. Csupor-Löffler B, Hajdú Z, Zupkó I, Réthy B, Falkay G, Forgo P, Hohmann J. 14 Antiproliferative effect of flavonoids and sesquiterpenoids from Achillea millefolium s.1. on 15 cultured human tumour cell lines. Phytother Res 2009; 23: 672-676

16 28. Hu LH, Zou HB, Gong JX, Li HB, Yang LX, Cheng W, Zhou CX, Bai H, Guéritte F, Zhao Y.

17 Synthesis and biological evaluation of a natural ester sintenin and its synthetic analogues. J

$18 \quad$ Nat Prod 2005; 68: 342-348

19 29. Sadowski-Debbing K, Coy JF, Mier W, Hug H, Los M. Caspases--their role in apoptosis and 20 other physiological processes as revealed by knock-out studies. Arch Immunol Ther Exp $21 \quad$ (Warsz) 2002; 50: 19-34

22 30. Krysko DV, Vanden Berghe T, D'Herde K, Vandenabeele P. Apoptosis and necrosis: 23 detection, discrimination and phagocytosis. Methods 2008; 44: 205-221 
1 31. Chandra J, Samali A, Orrenius S. Triggering and modulation of apoptosis by oxidative stress.

$2 \quad$ Free Radic Biol Med 2000; 29: 323-33

3 32. Ghantous A, Nasser N, Saab I, Darwiche N, Saliba NA. Structure-activity relationship of

4 seco-tanapartholides isolated from Achillea falcata for inhibition of HaCaT cell growth. Eur J

$5 \quad$ Med Chem 2009; 44: 3794-3797

6 33. Ahn H, Kim JY, Lee HJ, Kim YK, Ryu J-H. Inhibitors of inducible nitric oxide synthase

7 expression from Artemisia iwayomogi. Arch Pharm Res 2003; 26: 301-305

8 34. Bohlmann F, Zdero C, King HR, Robinson EH. Pseudoguaianolides and other sesquiterpene

$9 \quad$ lactones from Gaillardia species. Phytochemistry 1984; 23: 1979-1988

10 35. Trajkovic V, Vuckovic O, Stosic-Grujicic S, Miljkovic D, Popadic D, Markovic M,

11 Bumbasirevic V, Backovic A, Cvetkovic I, Harhaji L, Ramic Z, Mostarica Stojkovic M.

12 Astrocyte-induced regulatory T cells mitigate CNS autoimmunity. Glia. 2004; 47: 168-179

13 36. Kaludjerovic GN, Miljkovic D, Momcilovic M, Djinovic VM, Mostarica Stojkovic M, Sabo TJ,

14 Trajkovic $V$. Novel platinum(IV) complexes induce rapid tumor cell death in vitro. Int J

15 Cancer 2005; 116: 479-486

16 


\section{$1 \quad$ Figure legends}

2

$3 \quad$ Fig. 1 The structures of compounds 1-7.

5 Fig. $2 \operatorname{COSY}(\mathrm{a}: \multimap$ ) and $\operatorname{NOESY}(\mathrm{b}, \cdots y)$ correlations of $\mathbf{1}$.

6

7 Fig. 3 TOCSY correlations $(\longleftarrow$ ) of 3.

9 Fig. 4. Antiglioma effects of compounds 3, 4 and 6. C6 cells, U251 cells and rat primary

10 astrocytes were incubated with different concentrations of compounds $\mathbf{3 , 4 , 6}$, or cisplatin, and

11 mitochondrial respiration (MTT) and cell numbers (crystal violet) were assessed after $24 \mathrm{~h}$ (the

12 dashed lines represents the viability of untreated cells, which was arbitrarily set to $100 \%$ ). The

13 results are presented as mean $\pm \mathrm{SD}$ values from three independent experiments.

15 Fig. 5 Compound 3 induces apoptosis in glioma cells. (A-C) U251 cells (left) and C6 cells (right) 16 were incubated with $12.5 \mu \mathrm{M}(\mathrm{A})$ or $25 \mu \mathrm{M}(\mathrm{A}-\mathrm{C})$ of compound 3 for $24 \mathrm{~h}$. Cells were stained 17 with pan-caspase inhibitor ApoStat (A), PI (B) or annexinV-FITC/PI (C), and caspase activity 18 (A), DNA fragmentation (B) and phoshatidyl-serine exposure (C) were assessed using flow 19 cytometry. The histograms (A, B) and dot-plots (C) from a representative of three independent 20 experiments are presented.

22 Fig. 6 Compound 3 induces oxidative stress and mitochondrial depolarization in glioma cells. (A) $23 \mathrm{U} 251$ and C6 cells were incubated with compound $3(12.5 \mu \mathrm{M}$ or $25 \mu \mathrm{M})$ for $24 \mathrm{~h}$ and ROS 24 production in DHR-stained cells was investigated using flow cytometry. The histograms from a 
2

1 representative of three independent experiments are shown. (B) C6 cells were incubated with 2 compound $3(25 \mu \mathrm{M})$ for $24 \mathrm{~h}$ and mitochondrial membrane potential in DePsipher-stained cells

3 was assessed using flow cytometry. The histograms from a representative of three independent

4 experiments are presented (the values of FL1/FL2 are mean fluorescence ratios reflecting 5 mitochondrial depolarization). 
Table 1 NMR data of 1, $3\left(500 \mathrm{MHz}\right.$ for $\left.{ }^{1} \mathrm{H}, \mathrm{CDCl}_{3}\right)$ and $2\left(200 \mathrm{MHz}\right.$ for $\left.{ }^{1} \mathrm{H}\right)$

\begin{tabular}{|c|c|c|c|c|c|}
\hline \multirow{2}{*}{$\mathrm{H} / \mathrm{C}$} & \multicolumn{2}{|l|}{1} & \multirow{2}{*}{$\frac{2}{\delta_{\mathrm{H}}}$} & \multicolumn{2}{|l|}{3} \\
\hline & $\delta_{\mathrm{H}}$ & $\delta_{\mathrm{C}}^{\mathrm{a}}$ & & $\delta_{\mathrm{H}}$ & $\delta_{\mathrm{C}}^{\mathrm{a}}$ \\
\hline 1 & 4.24 brd (10.0) & 86.1 & $4.16 \operatorname{brd}(9.8)$ & & $\mathrm{c}$ \\
\hline $2 \alpha$ & $2.50 d d d d(1.5,5.0,13.0)$ & 34.8 & $2.55 d d d(1.5,5.0,12.8)$ & & 40.7 \\
\hline $2 \beta$ & $2.11 \mathrm{~m}^{\mathrm{b}}$ & & $2.05 \mathrm{~m}^{\mathrm{b}}$ & $2.34 d d(2.2,18.4)$ & \\
\hline 3 & $5.33 d d(5.0,11.5)$ & 75.6 & $5.29 d d(5.0,11.4)$ & 4.31 brd (4.8) & 79.8 \\
\hline 4 & & 144.2 & & & 173.1 \\
\hline 5 & $5.45 \mathrm{brd}(10.5)$ & 122.2 & $5.39 \operatorname{brd}(10.4)$ & & $\mathrm{c}$ \\
\hline 6 & $4.31 d d(9.5,10.0)$ & 79.0 & $4.33 t(10.0)$ & 5.06 brd (4.6) & 77.0 \\
\hline 7 & $2.84 d d d(2.0,10.0,10.0)$ & 46.8 & $2.05 \mathrm{~m}^{\mathrm{b}}$ & $3.19 m$ & 40.5 \\
\hline $8 \alpha$ & $2.29 \operatorname{brd}(14.5)$ & 33.2 & $2.45 \mathrm{~m}$ & $2.09 t(7.0)$ & 34.2 \\
\hline $8 \beta$ & $1.93 \operatorname{brdd}(14.5,10.0)$ & & $2.05 m^{\mathrm{b}}$ & & \\
\hline 9 & $5.14 b r d(10.5)$ & 76.8 & 5.10 brdd $(3.2,7.6)$ & $5.13 t(6.8)$ & 75.5 \\
\hline 10 & & 145.3 & & & $\mathrm{c}$ \\
\hline 11 & & 138.0 & 2.74 quint (7.6) & & 138.0 \\
\hline 12 & & 168.8 & & & $\mathrm{c}$ \\
\hline 13 & $6.28 d(3.5)$ & & $1.19 d(7.6)$ & $6.40 d(2.6)$ & \\
\hline & & 119.8 & & & 124.0 \\
\hline $13^{\prime}$ & $5.52 d(3.0)$ & & & $5.67 d(2.0)$ & \\
\hline 14 & $5.56 b r s$ & 117.6 & $5.56 \mathrm{brs}$ & $2.16 s^{\mathrm{b}}$ & 29.6 \\
\hline $14^{\prime}$ & 5.46 brs & & $5.48 \mathrm{brs}$ & & \\
\hline 15 & $1.58 \mathrm{brs}$ & 12.6 & $1.58 d(1.6)$ & $2.16 s^{\mathrm{b}}$ & 14.3 \\
\hline $\mathrm{OOH}$ & $8.75 \mathrm{brs}$ & & & & \\
\hline \multirow[t]{2}{*}{$\mathrm{OAc}$} & $2.08 s^{\mathrm{b}}$ & 170.2 & $2.08 s$ & $2.17 s$ & 171.2 \\
\hline & & 20.7 & & & 20.6 \\
\hline \multirow[t]{2}{*}{ OAc } & $2.06 s^{\mathrm{b}}$ & 169.4, & $2.03 s$ & I & I \\
\hline & & 21.0 & & & \\
\hline $\mathrm{OMe}$ & I & l & I & $3.42 s$ & 57.6 \\
\hline
\end{tabular}


${ }^{\mathrm{a}}$ Detected via HSQC and HMBC spectra. ${ }^{\mathrm{b}}$ Overlapped signals. ${ }^{\mathrm{c}}$ Not observed.

Table 2. $\mathrm{IC}_{50}$ values for compounds $\mathbf{3}, \mathbf{4 , 6}$, and cisplatin, presented as mean $\pm \mathrm{SD}$ from three independent experiments $\left({ }^{*} \mathrm{p}<0.05\right.$ compared to 4 , t-test; $\mathrm{CV}$ - crystal violet, n.a. - not assessed).

\begin{tabular}{lcccccccc}
\hline & \multicolumn{2}{c}{ comp. 6 } & \multicolumn{2}{c}{ comp. 4 } & \multicolumn{2}{c}{ comp. 3 } & \multicolumn{2}{c}{ cisplatin } \\
& MTT & CV & MTT & CV & MTT & CV & MTT & CV \\
\hline U251 & $>100$ & $>100$ & $91.8 \pm 7.9$ & $97.7 \pm 9.4$ & $36.6 \pm 6.8^{*}$ & $50.9 \pm 7.2^{*}$ & $20.8 \pm 4.3$ & $18.9 \pm 3.2$ \\
C6 & $>100$ & $>100$ & $80.1 \pm 9.6$ & $90.0 \pm 10.5$ & $41.6 \pm 8.5^{*}$ & $66.6 \pm 9.5^{*}$ & $15.0 \pm 5.7$ & $17.6 \pm 4.1$ \\
astrocytes & n.a. & n.a. & $>100$ & $61.8 \pm 15.6$ & $>100$ & $>100$ & $42.1 \pm 9.1$ & $25.5 \pm 5.1$ \\
\hline
\end{tabular}


Fig. 1

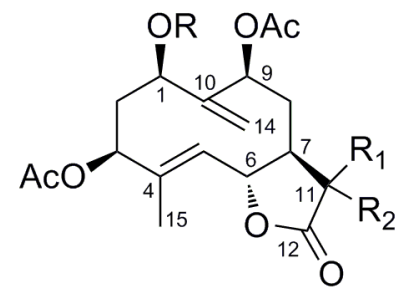

$1 \mathrm{R}=\mathrm{OH}, \mathrm{R}_{1}, \mathrm{R}_{2}=\mathrm{CH}_{2}$

$2 \mathrm{R}=\mathrm{H}, \mathrm{R}_{1}=\mathrm{Me}, \mathrm{R}_{2}=\mathrm{H}$

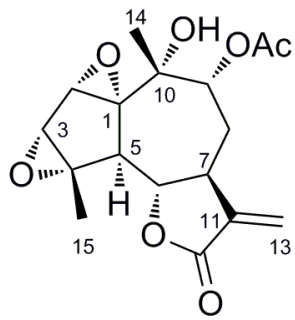

5

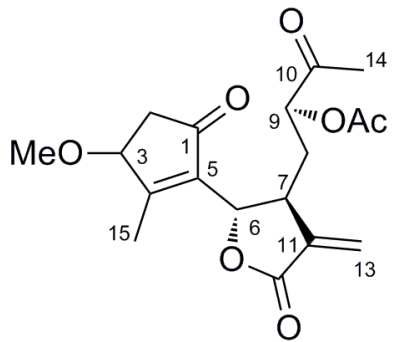

3

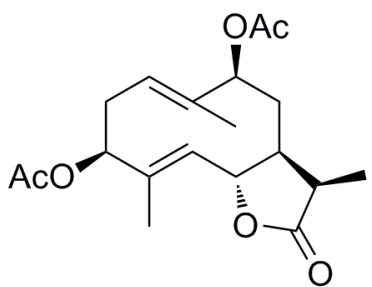

6<smiles>C=C1C(=O)O[C@@H]2[C@H]3[C@@]4(C)C=C[C@@]3(CO4)[C@](C)(O)C(OC(C)=O)C[C@H]12</smiles>

4

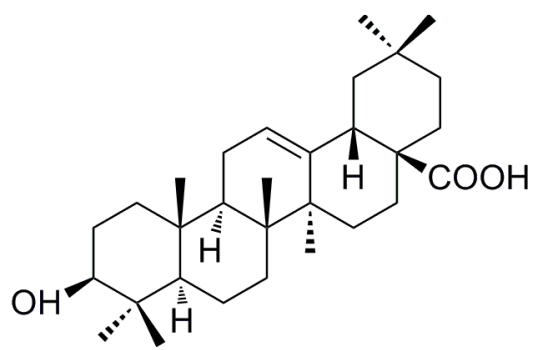

7 
Fig. 2
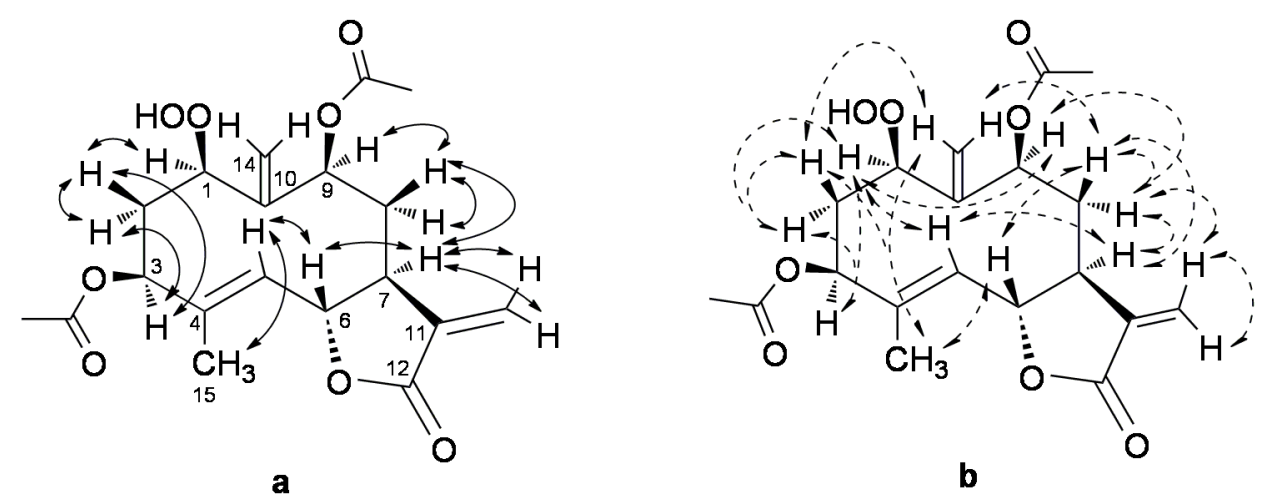

20

21

22

23

24

25

26

27

28

29

30

31

32

33

34

35

36

37

38

39

40

41

42

43

44

45

46

47

48

49

50

51

52

53

54

55

56

57

58

59

60 
Fig. 3

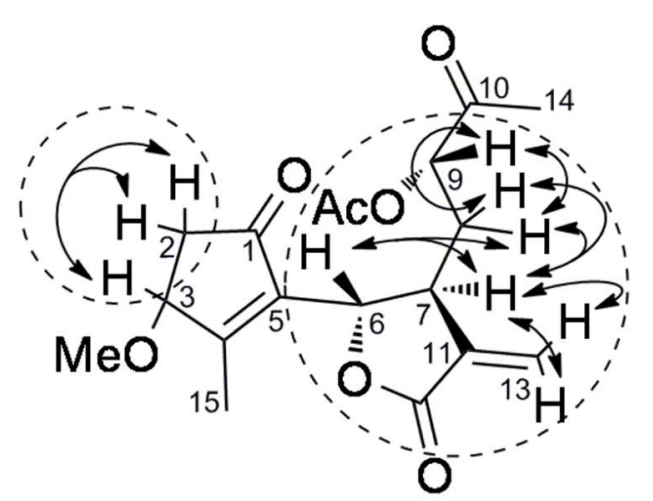

20

21

22

23

24

25

26

27

28

29

30

31

32

33

34

35

36

37

38

39

40

41

42

43

44

45

46

47

48

49

50

51

52

53

54

55

56

57

58

59

60 
Fig. 4
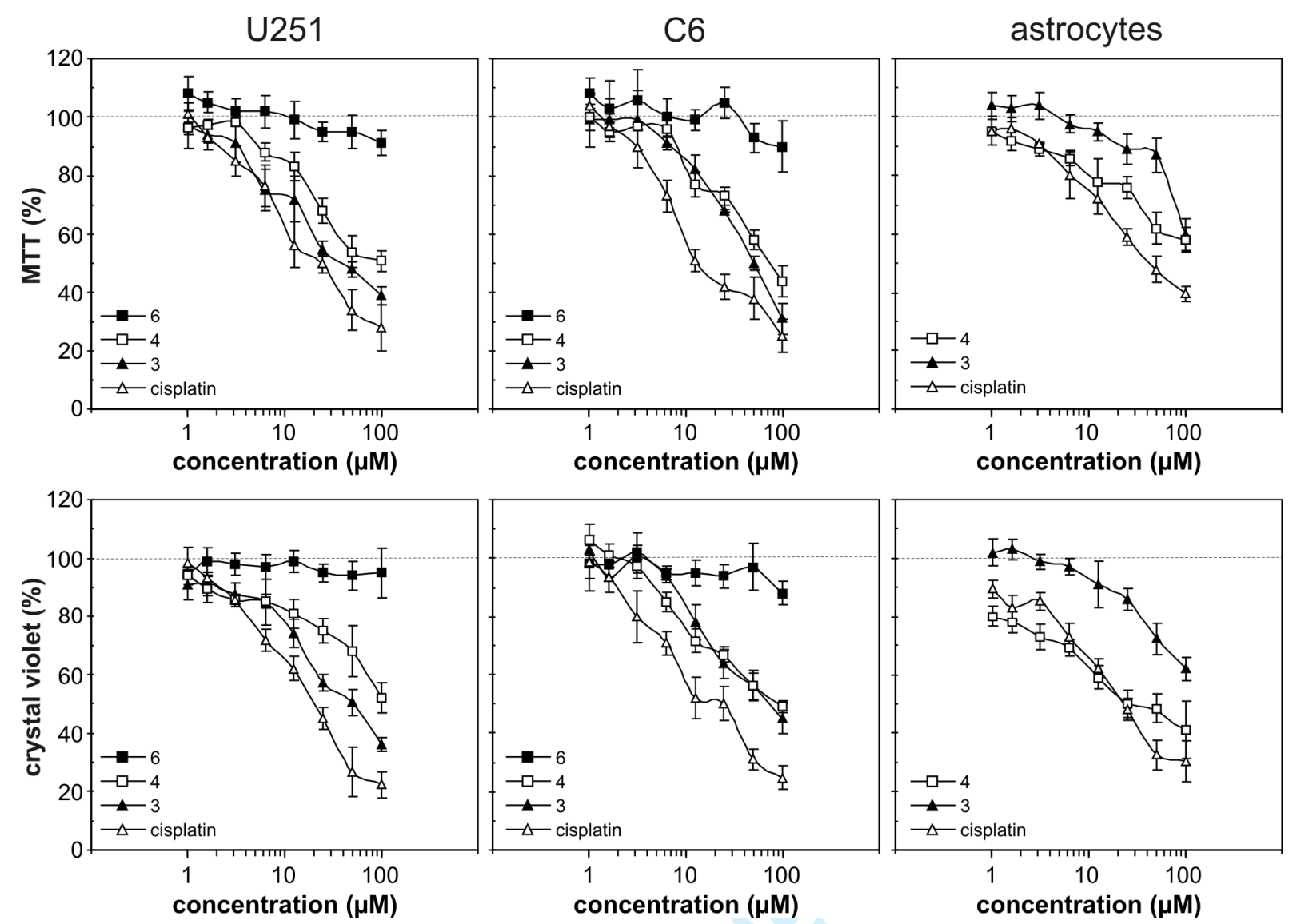

36

37

38

39

40

41

42

43

44

45

46

47

48

49

50

51

52

53

54

55

56 
Fig. 5
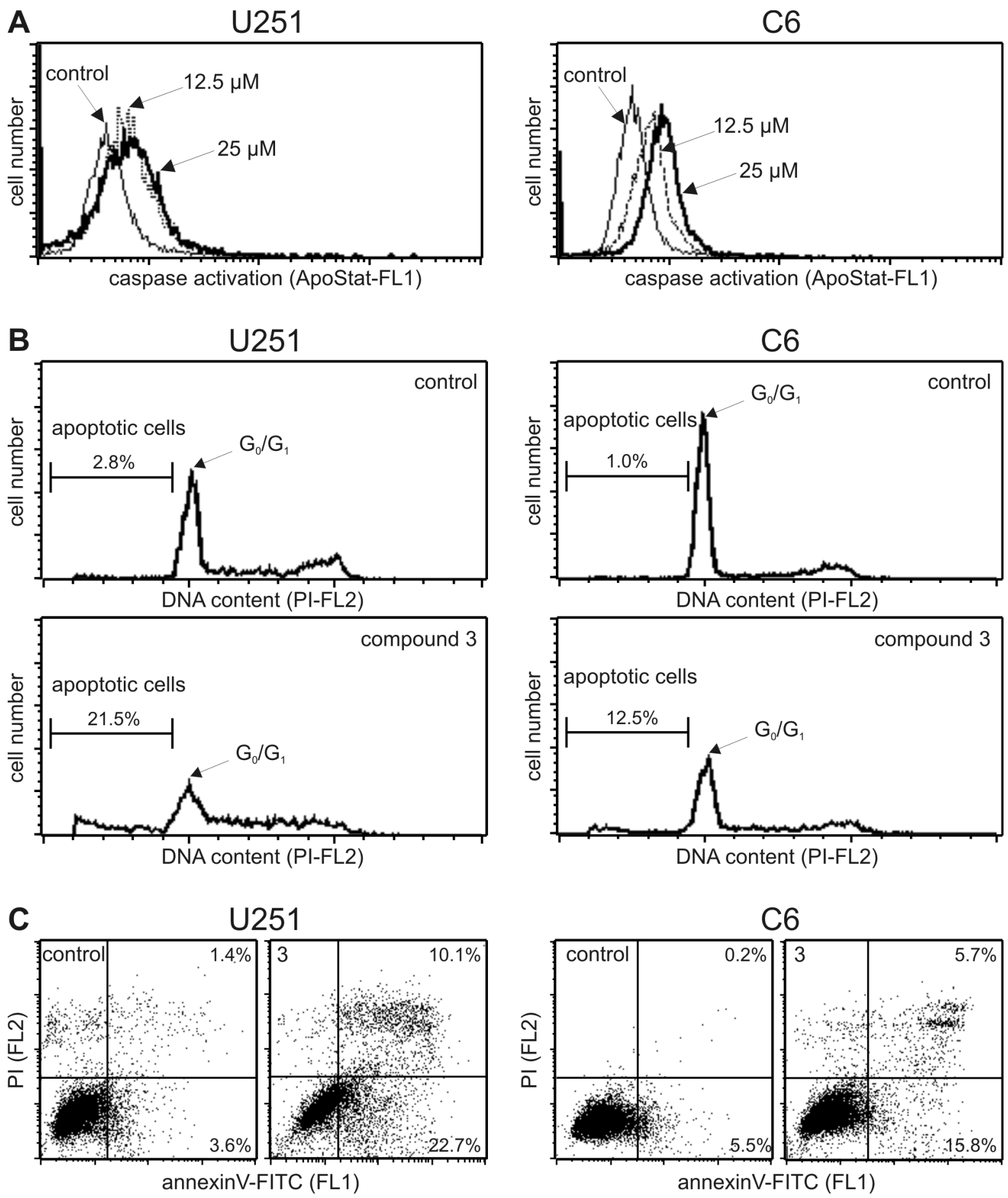
Fig. 6
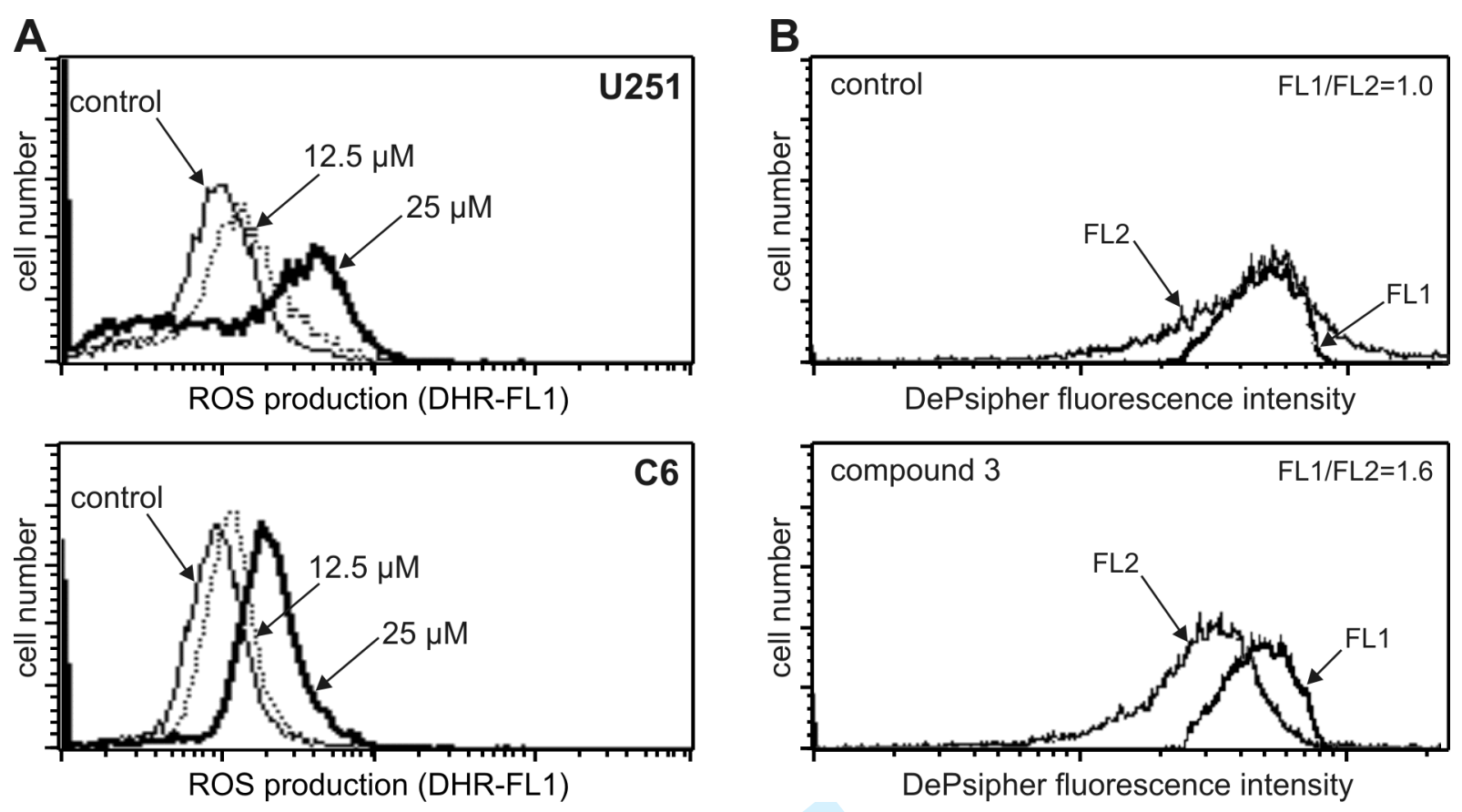


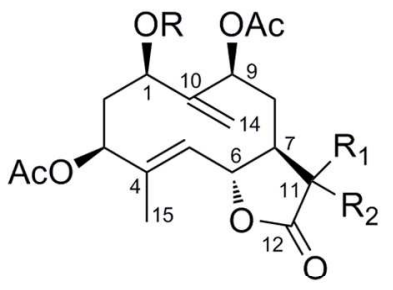

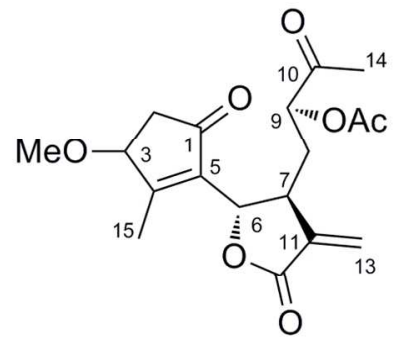

3
$2 \mathrm{R}=\mathrm{H}, \mathrm{R}_{1}=\mathrm{Me}, \mathrm{R}_{2}=\mathrm{H}$

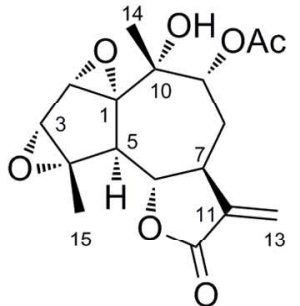

5

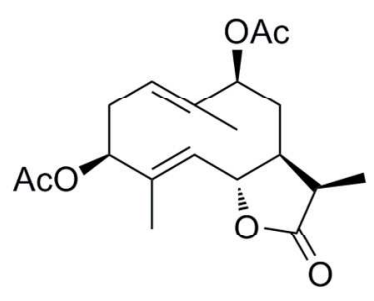

6

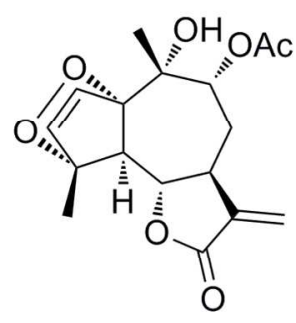

4

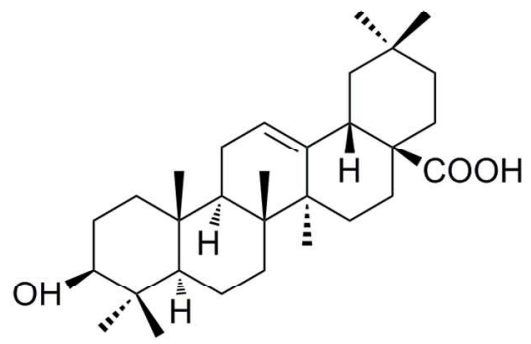

7

$134 \times 84 \mathrm{~mm}(300 \times 300$ DPI $)$

29

32

33

34

35

36

37

38

39

40

41

42

43

44

45

46

47

48

49

50

51

52

53

54

55

56

57

58

59

60 


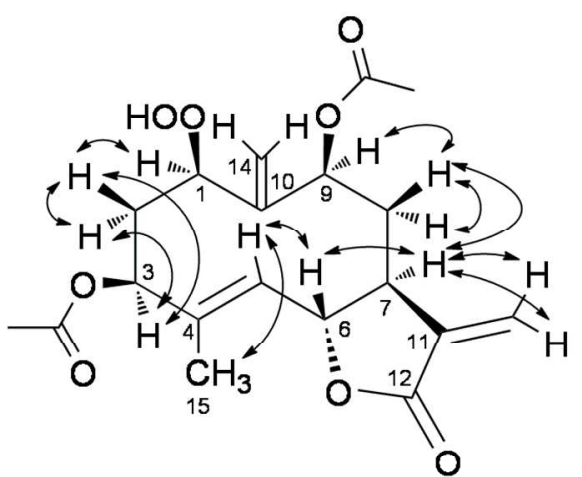

a

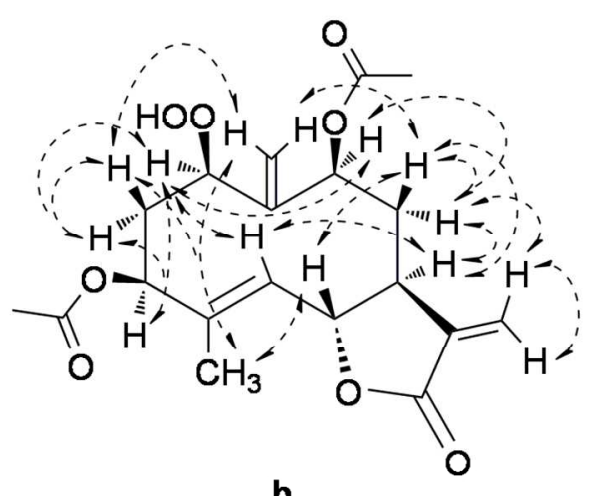

b

Fig. 2

$126 \times 54 \mathrm{~mm}(300 \times 300$ DPI $)$ 


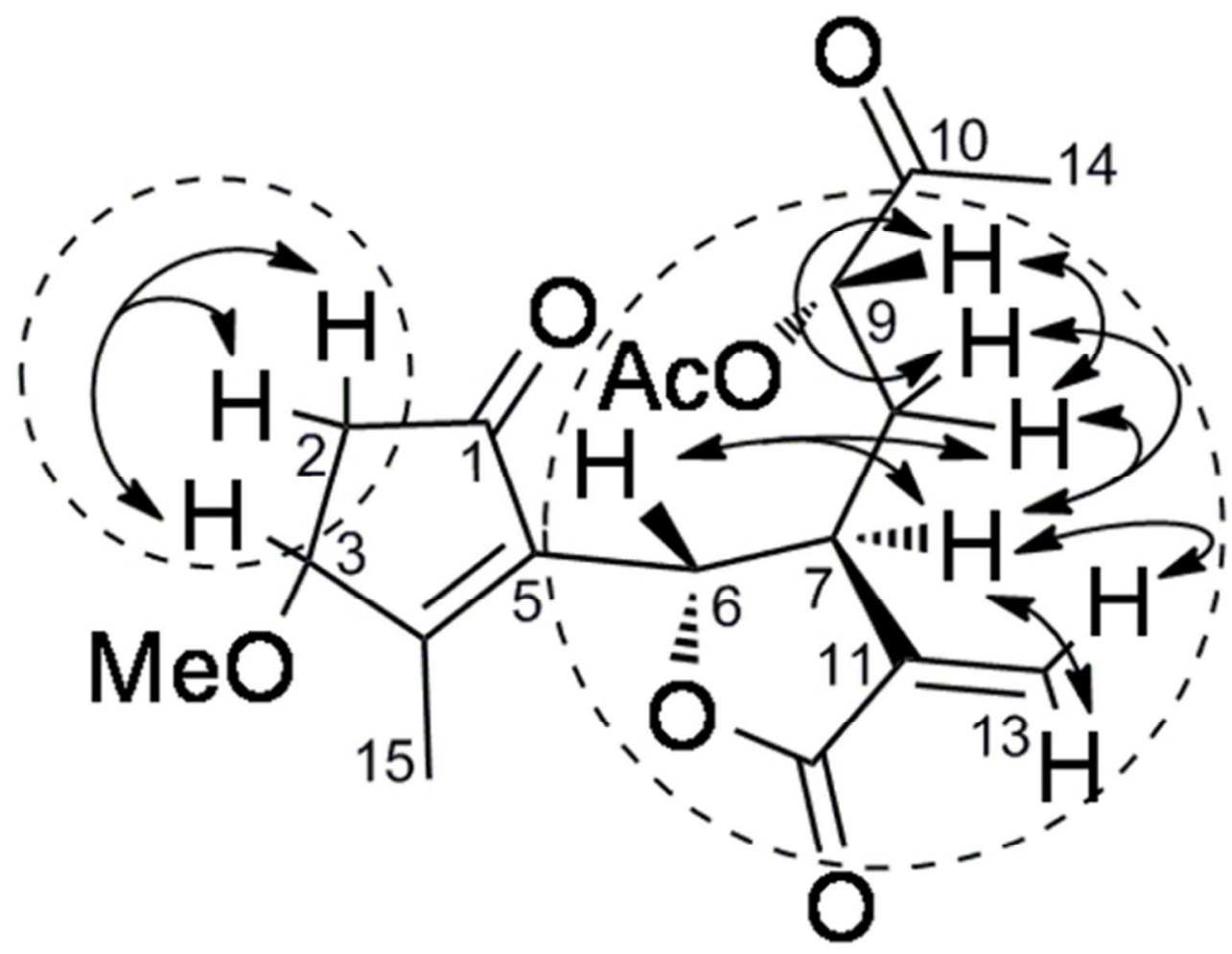

Fig. 3

$64 \times 50 \mathrm{~mm}(300 \times 300 \mathrm{DPI})$ 

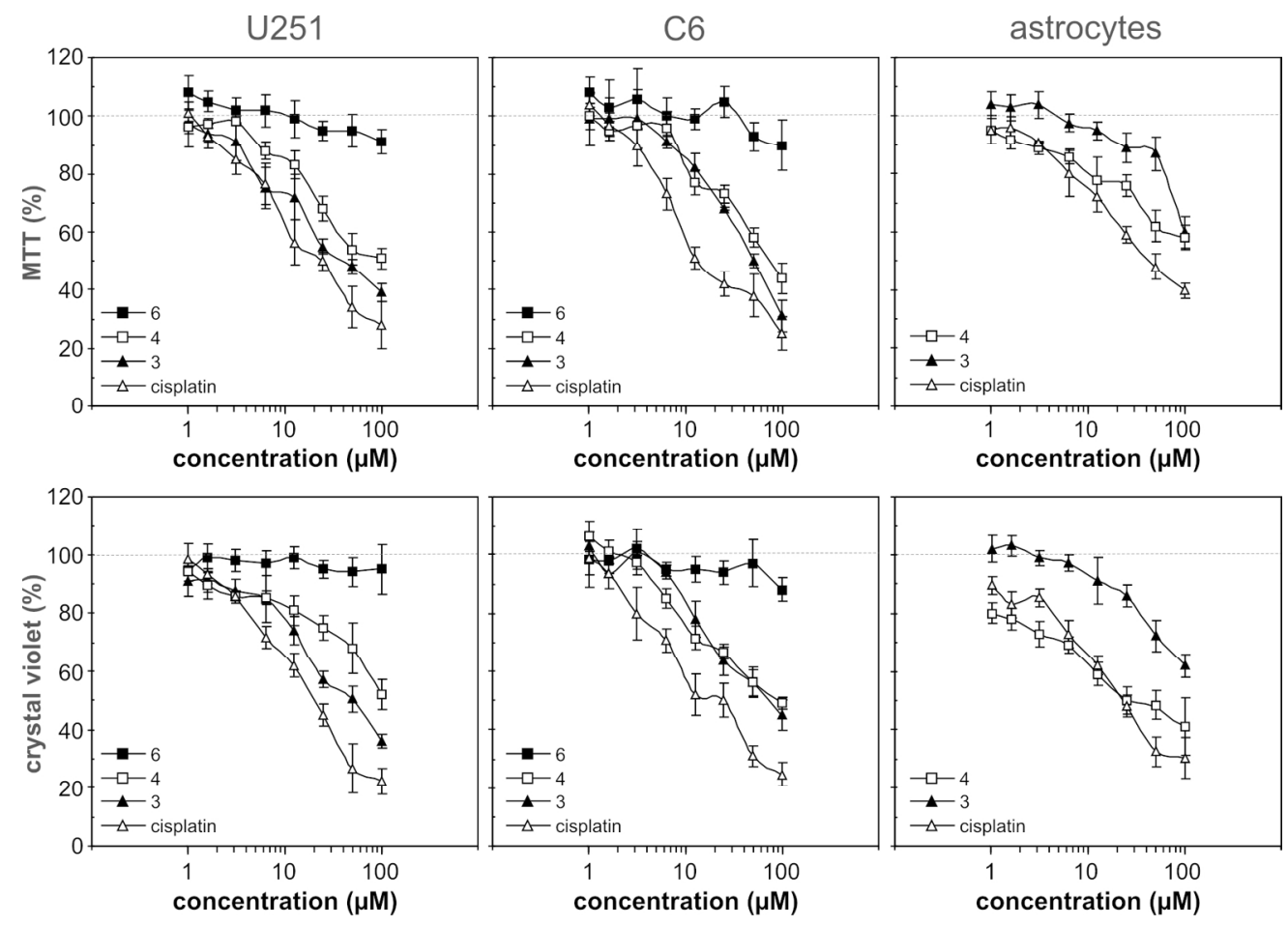

$160 \times 114 \mathrm{~mm}(300 \times 300 \mathrm{DPI})$ 

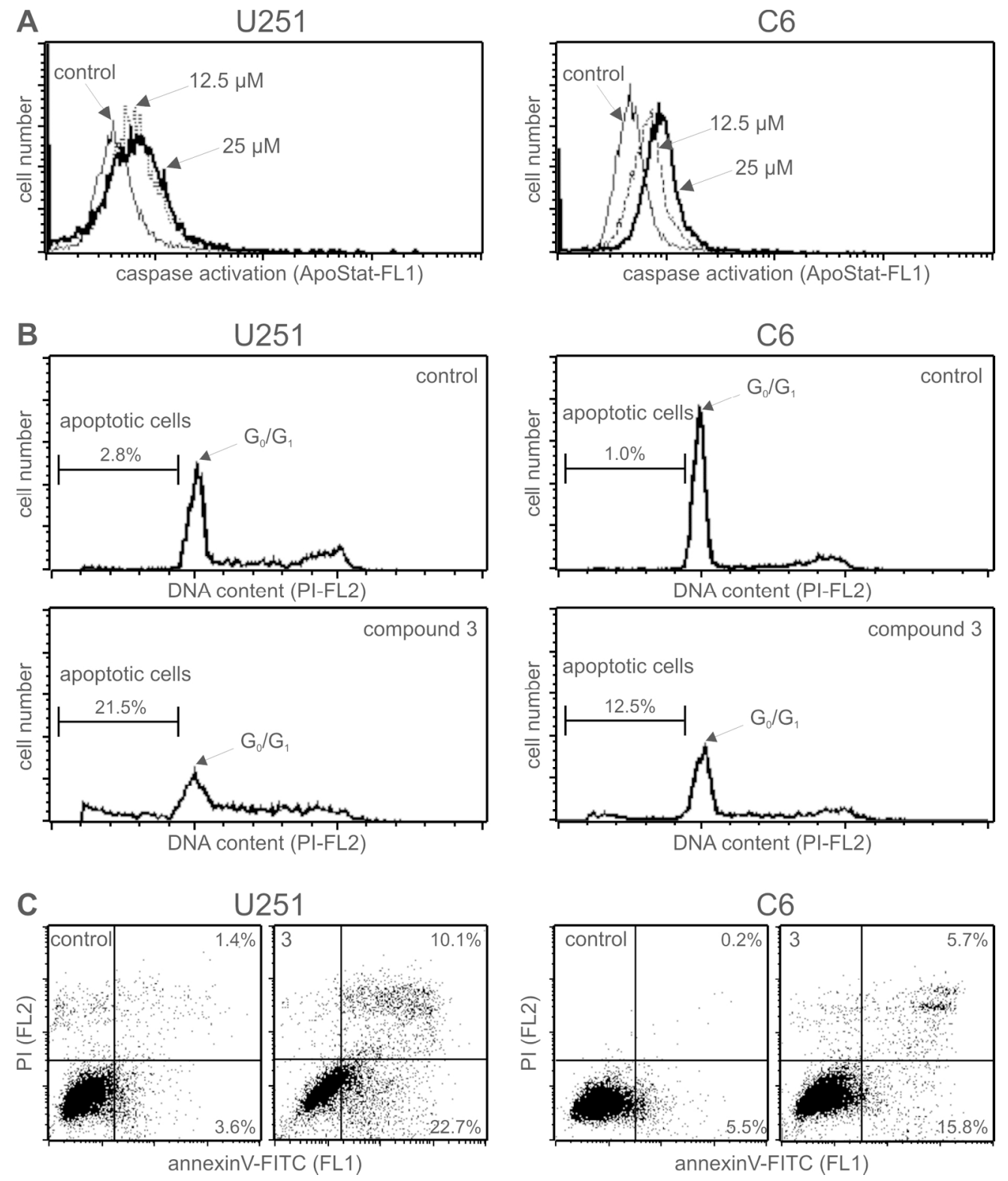

$157 \times 187 \mathrm{~mm}(300 \times 300$ DPI $)$ 

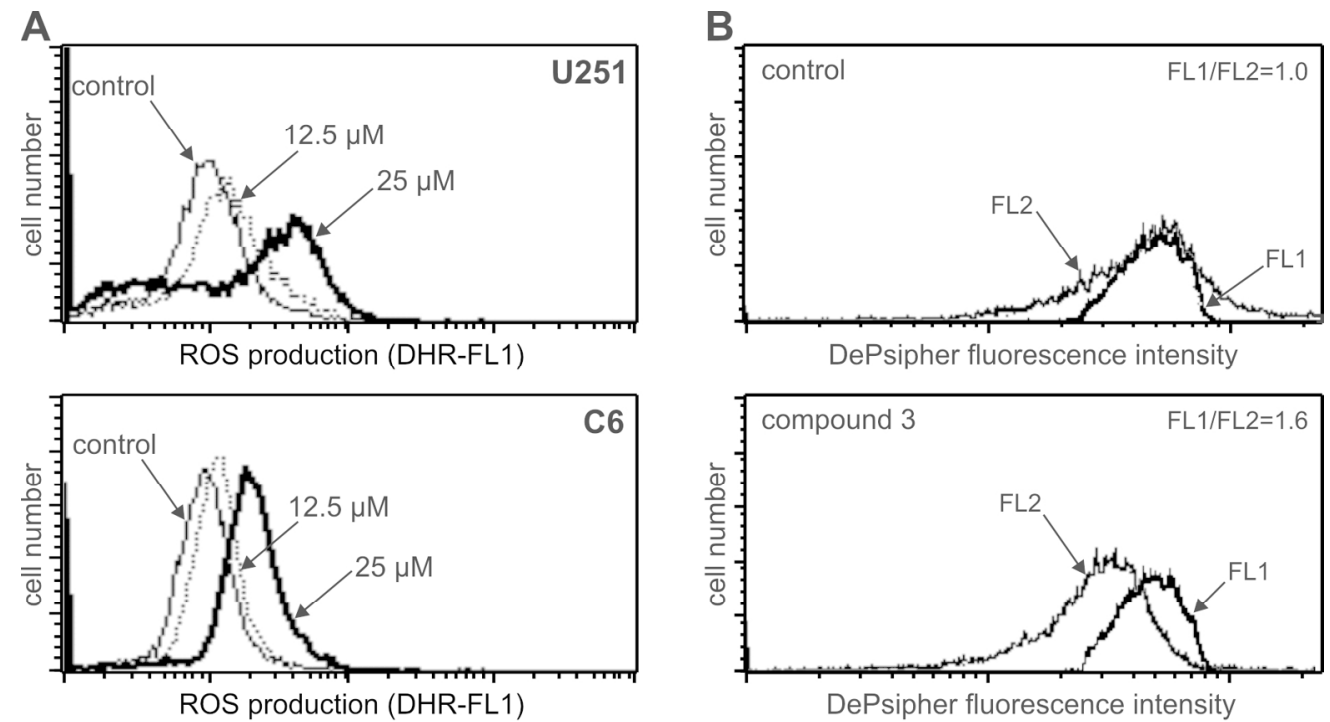

$160 \times 87 \mathrm{~mm}(300 \times 300 \mathrm{DPI})$ 